A CONTRIBUTION TO THE TAXONOMY OF, THE GENUS ANOPLIUS DUFOUR (HYMENOPTERA : POMPILIDAE) INCLUDING
A REVISION OF THE PALAEOTROPICAL SUBGENUS ORIENTANOPLIUS HAUPT

BY

MICHAEL CHARLES DAY

Pp. 373-404; 29 Text-figures

BULLETIN OF

THE BRITISH MUSEUM (NATURAL HISTORY) ENTOMOLOGY Vol. 30 No. 8

LONDON : 1974 
the Bulletin OF The BRitish Museum (NATURAL HISTORY), instituted in I949, is issued in five series corresponding to the Departments of the Museum, and an Historical series.

Parts will appear at irregular intervals as they become ready. Volumes will contain about three or four hundred pages, and will not necessarily be completed within one calendar year.

In I965 a separate supplementary series of longer papers was instituted, numbered serially for each Department.

This paper is Vol. 30 No. 8 of the Entomological series. The abbreviated titles of periodicals cited follow those of the World List of Scientific Periodicals.

World List abbreviation Bull. Br. Mus. nat. Hist. (Ent.)

(C) Trustees of the British Museum (Natural History), I974 


\title{
A CONTRIBUTION TO THE TAXONOMY OF THE GENUS ANOPLIUS DUFOUR \\ (HYMENOPTERA : POMPILIDAE) INCLUDING A REVISION OF THE PALAEOTROPICAL SUBGENUS ORIENTANOPLIUS HAUPT
}

\author{
By MICHAEL C. DAY
}

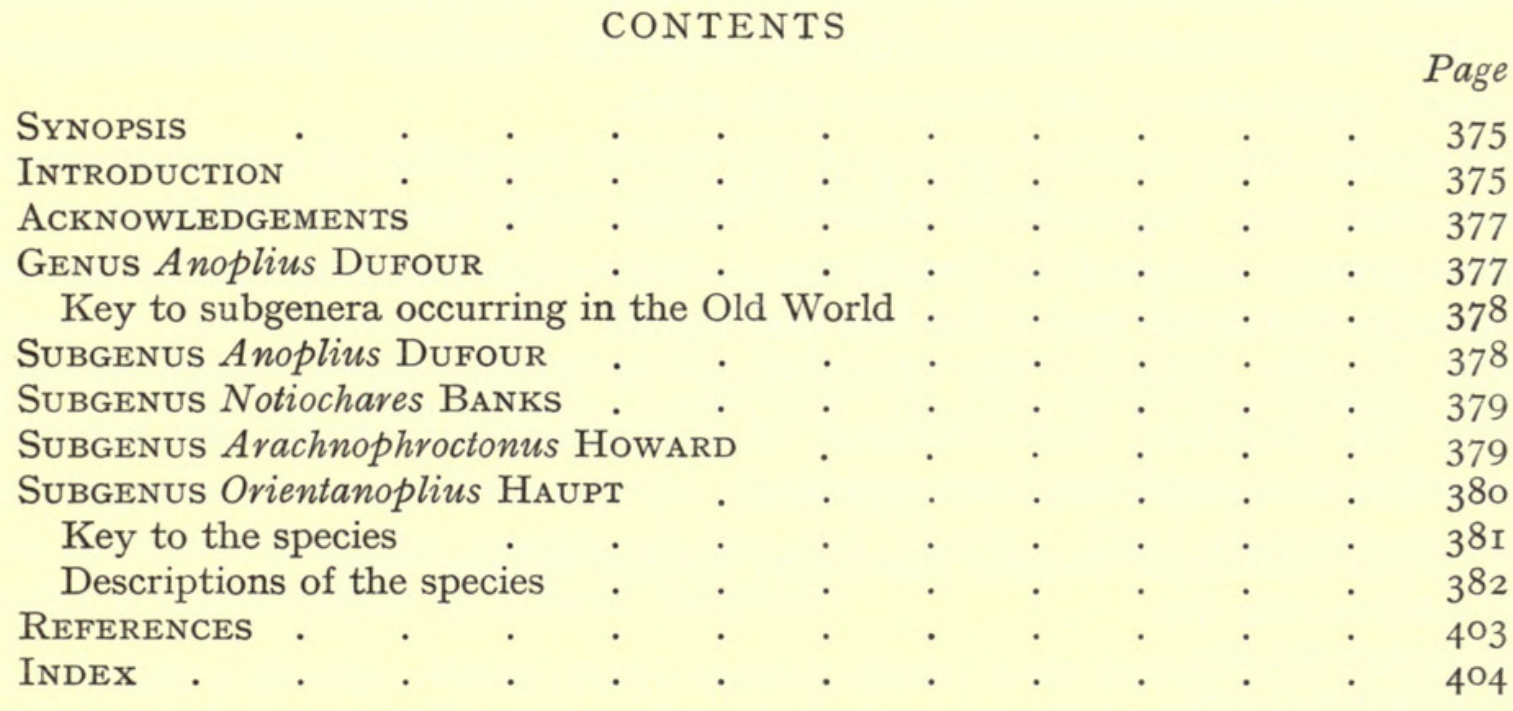

SYNOPSIS

The limits of the subgenera of Anoplius are re-assessed to accommodate the Old World species more satisfactorily. Two subgeneric synonyms are newly established and a key to subgenera is provided. Orientanoplius is used as a subgenus for the first time. Five species of this subgenus are revised and a sixth described as new. Distributional and biological data are summarized and a key to species provided. Lectotypes are designated for ten nominal species and fifteen specific synonyms are newly established. Seven nominal species are transferred from Orientanoplius to Anoplius s. str., and one specific synonym newly established in Notiochares.

\section{INTRODUCTION}

THE genus Anoplius Dufour is considered to be a natural group of Pompilini of cosmopolitan distribution. Evans (I95I; I966) has revised the species of North and Central America, where the genus is especially well represented. Evans was first to employ a satisfactory subgeneric framework for groups of close affinity within the genus. Haupt (I929) dealt with certain Old World species; Arnold (I937) gave a key to females of some Ethiopian species. Wolf (Ig63) revised the western 
Palaearctic species, following Evans in the employment of subgenera. No comprehensive accounts of the Old World fauna have been produced, although many species have been described and some genera proposed in a variety of faunal works.

Haupt (I935) proposed Orientanoplius as a genus for certain species of Anoplius from the Oriental region, whilst retaining Anoplius for some other species. Most of the species that Haupt placed in Orientanoplius are in fact members of Anoplius s. str. (new combinations are herein published). However, the type-species of Haupt's genus belongs to a natural group of Oriental and Ethiopian species which are well differentiated within Anoplius s. 1., and for which I believe the use of Orientanoplius as a subgenus is justified. Subsequently, Haupt (I950) proposed Africanoplius as a genus for the Ethiopian species which are here considered to be members of Orientanoplius.

It is the purpose of this paper to revise the species of this small group, since most other Old World species of Anoplius s. 1. are assignable to defined subgenera which may be revised satisfactorily as separate entities. It is envisaged that subsequent publications will complete this work.

There remain some isolated species of Old World Pompilini of restricted geographical occurrence (e.g. Tagalochares plutonis Banks, I934, from the Philippines) which are not at present assigned to Anoplius s. 1., but which may be when better studied. In most such instances, males are not yet known.

I have largely followed the terminology of Evans (I95I; I966) throughout, including his standard abbreviations of morphological terms; for convenience, those used in this paper are here repeated.

MID: middle interocular distance (maximum distance between eyes)

OOL: ocello-ocular line

POL: postocellar line

SGP: subgenital plate

SMC: submarginal cell

TFD: transfacial distance (width of head)

Depositories in which collections studied are housed are herein abbreviated as follows.

$\begin{array}{ll}\text { AM } & \text { Albany Museum, Grahamstown, Cape Province, Republic of South Africa. } \\ \text { ANIC } & \text { Australian National Insect Collection, Canberra, Australia. } \\ \text { ANS } & \text { Academy of Natural Sciences of Philadelphia, Pennsylvania, U.S.A. } \\ \text { BMNH } & \text { British Museum (Natural History), London. } \\ \text { IRSNB } & \text { Institut Royal des Sciences Naturelles de Belgique, Brussels, Belgium. } \\ \text { MCZ } & \text { Museum of Comparative Zoology, Boston, U.S.A. } \\ \text { MHN } & \text { Muséum d'Histoire Naturelle, Geneva, Switzerland. } \\ \text { MNHN } & \text { Muséum National d'Histoire Naturelle, Paris, France. } \\ \text { MNHU } & \text { Museum für Naturkunde der Humboldt-Universität, Berlin, East Germany. } \\ \text { MRAC } & \text { Musée Royal de l'Afrique Centrale, Tervuren, Belgium. } \\ \text { NM } & \text { Naturhistorisches Museum, Vienna, Austria. } \\ \text { NMSR } & \text { National Museum of Southern Rhodesia, Bulawayo, Rhodesia. } \\ \text { NR } & \text { Naturhistoriska Riksmuseum, Stockholm, Sweden. } \\ \text { RNH } & \text { Rijksmuseum van Natuurlijke Historie, Leiden, Netherlands. } \\ \text { TM } & \text { Transvaal Museum, Pretoria, Transvaal, Republic of South Africa. } \\ \text { UM } & \text { University Museum, Oxford, United Kingdom. }\end{array}$


USNM United States National Museum, Washington, U.S.A.

ZM Zoologisches Institut, Martin-Luther-Universität, Halle an der Saale, East Germany. coll.Wahis Private collection of Monsieur R. Wahis, Chaudfontaine, Belgium.

\section{ACKNOWLEDGEMENTS}

I am indebted to the following staff of other institutions who have arranged loans of type or other material: Dr C. Besuchet (MHN), Miss J. Cardale (ANIC), Dr J. Decelle (MRAC), Prof. H. E. Evans (MCZ), Dr G. Fagel (IRSNB), Mr F. W. Gess (AM), Prof. J. O. Husing (ZM), Dr S. Kelner-Pillault (MNHN), Dr E. Königsmann (MNHU), Mr J. Krikken (RNH), Dr A. S. Menke (USNM), Mr F. C. de Moor (NMSR), Mr C. O'Toole (UM), Dr P. I. Persson (NR), Mr J. van Reenan (TM), Miss P. Schuyler (ANS). I am grateful to Dr R. Crosskey for helpful discussion of points of procedure. I am particularly indebted to Monsieur R. Wahis for helpful discussion, and for the loan of specimens which were already the subject of his own research. Mr F. R. Wanless (BMNH) kindly identified spider prey.

\section{Genus ANOPLIUS Dufour}

Psammochares Latreille, I796 : II 5. Type-species: Sphex fusca Linnaeus, I76I, by subsequent designation (Latreille, I803 : I 58). [Suppressed by I.C.Z.N. Opinion I66, I945.]

Anoplius Dufour, 1834:483. Type-species: Sphex nigerrimus Scopoli, I763, by subsequent designation (Van der Vecht \& Menke, I968 : I20). [Ratified by I.C.Z.N. Opinion 997, I973.]

The diagnosis given by Evans (I966 : 2I4) requires modification in some particulars to accommodate the species of the Old World. That reproduced below is otherwise a transcription of Evans' diagnosis.

오 §ิ. Length 3-30 mm. Colour predominantly black, some species with abdomen partly or wholly reddish, a few with more or less red-brown coloration on head, thorax and legs; sometimes also with more or less pale yellow, more particularly in males, most frequently on the posterior pronotal margin. Apical tergite of female with at least a few stiff, backward directed bristles, often densely bristly. Mandibles with one or two teeth on inner margin. Labrum without a median slit, not or but slightly protruding from beneath clypeus, the latter truncate or emarginate. Malar space very short. Antennae elongate, segment three in female at least three times as long as wide. Pronotum rather short, without a median impression. Postnotum a transverse band of variable width, never expanded on each side of the median line. Propodaeum with smooth contours or with a well defined flat posterior declivity. Front tarsus of female with or without a comb; apical tarsal segment usually spined beneath but not always so. Claws of female usually dentate, occasionally bifid. Claws of male variable, usually markedly bifid with a strong tooth sub-equal in length to claw, occasionally dentate with a small but truncate tooth. Inner claws of male front tarsus either modified or not. Pulvillar comb strong, of from eight to twenty-four subparallel rays. Fore wing with three SMC's (rarely only two); hind wing with anal vein arching up to meet median vein at or slightly before cubital fork, occasionally slightly beyond; anal lobe at most half length of submedian cell. Male venter with or without tufts of hairs. Genitalia with basal hooklets single or absent, aedeagus simple and without spines or setae.

Females are readily recognized as generalized Pompilini with backward-directed bristles on the last tergite: males are best recognized by their possession of bifid claws and absence of other specialized features, or by the presence of distinct tufts 
or 'brushes' of hairs on the abdominal venter. In many instances (e.g. Orientanoplius), males do not conform well to any formal diagnosis, but present satisfactorily the overall facies of the genus.

Distribution. The subgenera Anoplius s. str. and Arachnophroctonus Howard are cosmopolitan, Lophopompilus Radoszkowski is holarctic. Anopliodes Banks, Notiochares Banks and Cameronoplius Evans are of more or less limited distribution in the New World tropics. Orientanoplius is confined to the Old World tropics.

Key to SUBgenera OF $A N O P L I U S$ OCCURRING IN THE OLD WorLD

Females

I Fore tarsus without a comb; i.e. the second tarsal segment without a spine on the outer side equal in length to that borne distally on the outer side of the segment

ANOPLIUS Dufour (p. 378)

- Fore tarsus with a comb of short or fairly long spines; i.e. the second tarsal segment bears an additional spine at least equal in length to that borne distally on the outer side of the segment

2 Posterior margin of pronotum arcuate; head, thorax and abdomen with abundant erect hair; anterior margin of clypeus with distinct median emargination

LOPHOPOMPILUS Radoszkowski

- Posterior margin of pronotum angulate or, rarely, arcuate: if arcuate, without abundant erect hair on head, thorax and abdomen; anterior margin of clypeus without median emargination

3 Ultimate tarsal segments without spines beneath

ORIENTANOPLIUS Haupt (p. 380)

- Ultimate tarsal segments with spines beneath

ARACHNOPHROCTONUS Howard (p. 379)

Males

I SGP with large plumose process at base, which projects from emargination of preceding sternite . $\quad . \quad$. $\quad . \quad$. . LOPHOPOMPILUS Radoszkowski

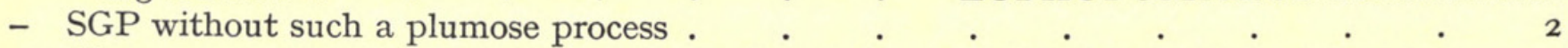

2 Claws apparently dentate; tooth not parallel to claw, much reduced; without brushes of hairs on abdominal venter . . . . ORIENTANOPLIUS Haupt (p. 380)

- Claws bifid: often with brushes of hairs on abdominal venter

3 Propodaeum, in profile, sloping evenly from front to rear, or gently rounded. Black or dark brown species, frequently with extensive grey or silvery pubescence. (One Ethiopian species with 3 or 4 pairs of orange maculae on abdominal tergites.)

ANOPLIUS Dufour (p. 378)

- Propodaeum, in profile, with a more or less abrupt declivity, or strongly rounded. Black or dark brown species, usually with extensive red, red-brown, or orange maculae on first tergites (occasionally reduced to one or two pairs of small spots, or absent)

ARACHNOPHROCTONUS Howard (p. 379)

\section{Subgenus ANOPLIUS Dufour}

Anoplius Dufour, $1834: 483$.

Anoplius s. str. is a large and rather diverse subgenus of cosmopolitan distribu- 
tion, but well characterized by the absence of a tarsal comb in the female, correlated with a specialization towards the use of pre-existing cavities as nesting sites. In particular, many species of the subgenus exhibit a preference for waterside and intermittent watercourse habitats. Many species in the Old World tropics are assignable here; the following names, originally proposed in Orientanoplius, are new combinations in Anoplius s.l. and are all assignable to Anoplius s. str.:

Anoplius apicalis Haupt, I938b :46. (Junior secondary homonym of Anoplius apicalis Haupt, I929. No new name is here proposed.) Comb. n.

Anoplius consimilis Haupt, I94I : 76 . Comb. n.

Anoplius melas Haupt, I935 : 316. Comb. n.

Anoplius minutidens Haupt, I94I : 79. Comb. n.

Anoplius niger Haupt, I938a: 16. Comb. n.

Anoplius nitens Haupt, I935 : 316. Comb n.

Anoplius obscuratus Haupt, I938b: 45. Comb. n.

Subgenus NOTIOCHARES Banks

Notiochares Banks, I9I7 : I07. Type-species: Pompilus philadelphicus Lepeletier, 1845 [=Pompilus atramentarius Dahlbom, I843], by monotypy.

\section{Anoplius (Notiochares) amethystinus exclusus (Smith)}

Pompilus exclusus Smith, I873 : 444. Holotype đే, BRAzIL (BMNH) [examined].

Pompilus viridicatus Smith, I879: I43. Holotype 우, 'West AfricA' (BMNH) [examined]. Syn. n.

Anoplius viridicatus (Smith); Arnold, I937 : 62.

Arnold (I937) redescribed the type of $P$. viridicatus, which is purported to be from West Africa. He was not familiar with the New World fauna, and did not recognize this common American pompilid The type-specimen may have been either a chance introduction to the West African coast or more probably was mislabelled at some stage subsequent to capture in the Americas. I have seen no African specimens taken since Arnold's redescription. Evans (I966) records the distribution of this subspecies as 'Windward Islands and Panama to Bolivia and N. Argentina'.

\section{Subgenus ARACHNOPHROCTONUS Howard}

Psammochares Latreille, I796: II 5. Type-species: Sphex fusca Linnaeus, I76I, by subsequent designation (Latreille, I803 : I58). Suppressed by I.C.Z.N. Opinion I66, I945.]

Arachnophroctonus Howard, I90I : pl. 7, figs II, I4. Type-species: Sphex tropicus Linnaeus sensu Fabricius, I775 (misidentification) [=Psammochares marginalis Banks, I9Io], by subsequent designation (Pate, I946: I29).

Pompilinus Ashmead, I902 : 85. Type-species: Pompilus cylindricus Cresson, I867, by monotypy. Syn. n.

The subgeneric names Arachnophroctonus and Pompilinus have been applied to closely related groups of species in the New World, although Evans recognized them to be widely distributed in the Old World also. Wolf (Ig63) has used Pompili- 
nus for Palaearctic species. Evans regards these as 'decidedly weak' entities (I966 : 302) and stated that they may not 'stand as discrete subgenera in the final analysis unless further characters are discovered to separate them' (Evans, I95I : 278). Study of the Old World fauna reinforces this conclusion; species which appear to be closely related would be distributed to different subgenera on the basis of characters currently used.

More than a dozen Old World species are assignable to Arachnophroctonus in the broad sense here employed. The most common Old World species have previously been placed in Pompilinus.

\section{Subgenus ORIENTANOPLIUS Haupt stat. n.}

Orientanoplius Haupt, I935 : 315 (as genus; proposed anew with same type-species, Haupt, I938a : I6). Type-species: Pompilus ignobilis Saussure, I867 [=Pompilus canifrons Smith, I 855$]$, by original designation.

Africanoplius Haupt, I950 : 40. Type-species: Pompilus morosus Smith, I855, by original designation. Syn. n.

우 §ิ․ Length 8-22 mm. Body colour black, with more or less grey pubescence, or various amounts of red-brown and yellow colouring; male pronotum margined posteriorly with yellow, sometimes obliterated by pale yellow-brown background or by silvery pubescence. With some strong erect hairs, particularly on front, temples, fore coxae, thoracic dorsum, propodaeum and abdominal venter. Wings infuscate, fusco-hyaline suffused with yellow, or yellow. Anterior margin of female clypeus transverse or concave. Front rather narrow. Pronotal hind margin angulate or arcuate. Fore tarsus with a comb of spines. Ultimate tarsal segments lack spines beneath. $\mathrm{SMC}_{3}$ of fore wing narrowed above, never petiolate. Male antenna in profile slightly to markedly crenulate. Terminal segment of male fore tarsus unmodified, claws more or less dentate rather than bifid (Text-fig. 28). Male venter without brushes or mats of hairs, SGP never flat, always folded longitudinally to a greater or lesser extent. Posterior margin of SGP always bordered by spines which are thicker than setae on ventral surface. Genitalia with basal hooklets well developed and single, or much reduced.

Distribution. Widely distributed in forest, woodland and savanna areas of the Old World tropics, including Madagascar and Queensland, Australia. Absent from drier areas.

Biology. No information has previously been published for this group of Anoplius. What little is known is summarized under A. canifrons, A. morosus and A. nigripes.

INCLUDED SPECIES. Six species are here recognized as members of Orientanoplius, three in the Ethiopian region, one Malagasy, and two Oriental. They fall conveniently into two species-groups which correlate with geographical distribution, here called the canifrons-group (Oriental species) and the morosus-group (Ethiopian and Malagasy).

There is no doubt that Haupt correctly identified the nominal species he designated as type-species of Orientanoplius; a female of $A$. canifrons from Kandy, Ceylon, collected by Dr Enslin in I929 and deposited in the collections of the ZM, Halle, bears Haupt's determination label 'Orientanoplius ignobilis Sauss: det. Haupt I932 ․' 


\section{KEY TO THE SPECIES OF ORIENTANOPLIUS}

\section{Females}

I Wings largely infuscate, normally with violaceous reflections. Body colour black, extensively covered with black or grey pubescence. Oriental region. (canifronsgroup)

- Wings largely yellow, with varying amounts of infuscation apically. Body colour various proportions of black and red-brown, sometimes with yellow maculae. Ethiopian region. (morosus-group)

2 Clypeus (when head viewed perpendicular to front) with distinctly arcuate margin (Text-fig. I6). Posterior pronotal margin distinctly angulate (Text-fig. I3). Mesonotum with at least some red-brown coloration

- Clypeus transverse (Text-fig. I7). Posterior margin of pronotum weakly angulate or arcuate (Text-figs I4, I5). Mesonotum entirely black . . . . .

3 Apical infuscation of forewing well defined, normally just entering distal tip of marginal cell. Mesonotum with a median wedge-shaped black area anteriorly, otherwise red-brown. Sixth tergite normally red-brown. Africa and Sao Thomé Island

morosus Smith (p. 388)

- Apical infuscation less clearly defined, diffuse, rarely just entering distal tip of marginal cell. Frequently much of thorax red-brown, lateral angles of posterior propodaeal margin frequently with a spot of yellow. Sixth tergite black saegeri Arnold (p. 394)

4 Forewing with apical infuscation occupying outer half or marginal cell, most of $\mathrm{SMC}_{3}$ and part of second discoidal cell. Pronotum often margined posteriorly with yellow: occasionally with other yellow maculae on thorax bifasciatus Tullgren (p. 400)

- Apical infuscation limited to area beyond closed cells. Without yellow margin to pronotum

nigripes Haupt (p. 396)

\section{Males}

I Head broader than high (TFD exceeds FD). Antennae distinctly crenulate. Genitalia with basal hooklets substantially reduced. Oriental region. (canifronsgroup)

- Head narrower (TFD approximately=FD). Antennae only slightly crenulate. Genitalia with basal hooklets normal, single. Ethiopian region. (morosusgroup)

2 Femora and tibiae 2 and 3 black, often with a yellow macula dorsally on tibia 3 . Tergites all black, all grey, or each is black anteriorly and grey posteriorly. Genitalia (Text-figs 2, 3) . . . . . . . . canifrons Smith (p. 382)

- Part of femora and tibiae light red-brown. Anterior tergites entirely grey, posterior tergites entirely black. Genitalia (Text-figs 6,7) . . . rufipes sp. n. (p. 387 )

3 Body colour black with more or less extensive yellow maculae; at least some spots of yellow on mesopleura and metapleura and centrally on propodaeum. Wings fuscohyaline with a tinge of yellow, infuscation more definite apically. Genitalia (Textfigs 26,27 ) .

bifasciatus Tullgren (p. 40o)

- Body colour black with varying amounts of red-brown; often with some yellow maculae, but if so never on meso- or metapleurae or centrally on propodaeum.

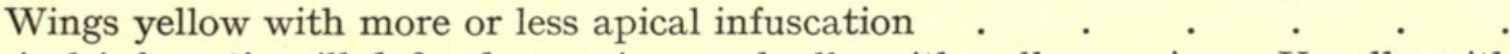

4 Apical infuscation ill-defined, merging gradually with yellow region. Usually with lateral spots of yellow on propodaeal flanges, and often with yellow maculae on some tergites. Genitalia (Text-figs 22, 23). Madagascar . . saegeri Arnold (p. 394)

- Apical infuscation well defined, covering $\mathrm{SMC}_{3}$ and most of marginal cell. Devoid of yellow maculae on mesothorax, metathorax, propodaeum or abdomen. African species 
$5 \mathrm{SMC}_{3}$ much narrowed above, much shorter on radial vein than is $\mathrm{SMC}_{2}$. Mesonotum red-brown, with a single median anterior black streak. Genitalia (Text-figs 2O, 2I)

morosus Smith (p. 388)

- $\mathrm{SMC}_{3}$ less narrowed above, frequently as long on radial vein as is $\mathrm{SMC}_{2}$. Mesonotum entirely black. Genitalia (Text-figs 24, 25)

nigripes Haupt (p. 396)

\section{THE CANIFRONS-GROUP}

․ Dark brown or black with more or less grey pubescence; wings substantially fuscous with more or less violaceous reflections.

๙. Head wider than high, antennae markedly crenulate, genitalia with basal hooklets much reduced.

Oriental region.

\section{Anoplius (Orientanoplius) canifrons (Smith) comb. n.}

(Text-figs $I-4,9)$

Pompilus canifrons Smith, I855 : I46. Holotype 오, Sumatra (BMNH) [examined].

Pompilus leucopheus Smith, I857:92. Holotype $\hat{\sigma}$. West Malaysia (UM) [examined]. Syn. n.

Pompilus limbatus Smith, I86r : 78. Holotype $ぇ$, Sulawesi (UM) [examined]. Syn. n.

Pompilus nigrocaeruleus Smith, I86I : 79. LECTOTYPE ㅇ, Sulawesi (UM), here designated [examined]. Syn. n.

Pompilus ignobilis Saussure, I867:60. LECTOTYPE + , CEYlon (MHN), here designated [examined]. Syn. n.

Pompilus rufounguiculatus Taschenberg, I869:54. Holotype 우, JAva (ZM) [examined]. Syn. n.

Pompilus atropos Smith, I879: I46. Holotype $ᄋ$, Sumatra (BMNH) [examined]. Syn. n.

Salius canifrons (Smith); Dalla Torre, I897:216 (new combination, erroneously attributed to Kohl, I884:45).

Psammochares pluto Turner, I9I 7 : 69. LECTOTYPE $ᄋ$, Australia (BMNH), here designated [examined]. Syn. n.

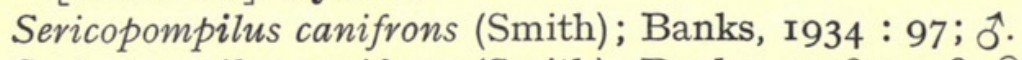

Sericopompilus canifrons (Smith); Banks, 1938 : 248; 우, ㅎ.

LECTOTYPE DESIGNATIONS.

(I) Pompilus nigrocaeruleus Smith. The description states 'length 9-Io lines', indicating that Smith described from more than one specimen. Two females in the Hope department (UM) bear circular locality labels ('Mak') and blue labels in Smith's handwriting, 'Pompilus nigro-coeruleus Smith'. I have labelled, and here designate as lectotype, the smaller specimen, which is in slightly better condition.

(2) Pompilus ignobilis Saussure. Described from four females collected by Humbert in Ceylon. Two female specimens in the main collections of the MHN, Geneva, bear labels in Saussure's handwriting, 'Pompilus ignobilis Sss'. The first bears a printed locality label 'Trincom. Ceylan', of the type normal for material collected by Humbert in Ceylon. The second specimen bears no such printed locality label, but a printed label 'Cn. de Saussure', on which 'Trincomalie' has been handwritten. This specimen also bears two other labels, one bearing the figures 


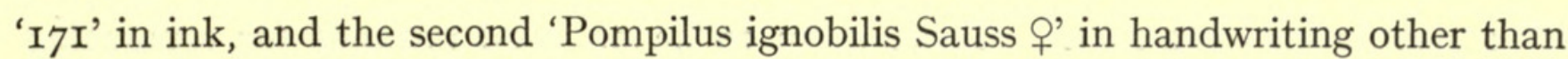
Saussure's. A third specimen from a box of miscellaneous Pompilidae bears a single printed label, 'Trincom. Ceylan', identical with that of the first specimen. The three are conspecific, and agree well with the description. Although none bear type-labels, I am satisfied that these are three syntypes of P. ignobilis Saussure; the putative fourth syntype has not been traced and may be presumed lost. The first specimen here recorded has been labelled and is here designated as lectotype.

(3) Psammochares pluto Turner. Described from a single female and a single male, both in the collections of the BMNH. I have labelled, and here designate as lectotype, the female specimen.

․ Length I2-2I mm. Dark violet-brown or black. Fore wing infuscate with violaceous reflections, wingtip often slightly darker. Hind wing with more or less hyaline area basally. Pubescence variable, most commonly extensive grey pubescence on face and clypeus, anterior and posterior parts of pronotum, most of thorax save mesonotum and dorsum of scutellum, anterior half of tergites, and variously on coxae and legs. Otherwise dark brown or black. The extent of grey pubescence may be reduced or totally absent. Face with a small yelloworange spot against inner orbit, sometimes absent, most frequently in dark-pubescent forms. Pubescence reflecting silvery on lower face and coxae, sometimes markedly so.

Apical margin of clypeus feebly to markedly concave. Inner orbits converging above, subparallel or diverging below. Front narrow, MID less than $0.5 \times$ TFD. POL exceeding OOL, variable. Posterior pronotal margin distinctly angulate. Propodaeum with a flattened declivity, not rounded laterally but more or less angular. Fore basitarsus with three combspines, $\mathrm{I} \cdot \mathrm{O}-\mathrm{I} \cdot 5 \times$ as long as median thickness of segments bearing them. $\mathrm{SMC}_{3}$ narrowed above, much shorter on radial vein than SMC2. Third transverse cubital vein slightly arched towards wingtip or sometimes virtually straight.

§. Length $8 \cdot 0-14.5 \mathrm{~mm}$. Coloration similar to female, but yellow on face varies from a thin strip bordering inner orbits to substantial areas of yellow extending onto clypeus and mandible, and bordering outer orbits, also hind margin of pronotum and ventral surface of scape, and dorsal surface of hind tibia. Proximal antennal segments often red-brown ventrally. Wings fuscous as in female, but fore wing frequently with hyaline areas basally also. Pubescence as in females, but grey-pubescent form with more substantial area of tergites so coloured. Silvery pubescence as females, often quite extensive.

Eyes converging above, subparallel or converging below, UID less than LID (Text-fig. I). Antennae distinctly crenulate distally. Propodaeum weakly arched longitudinally, broad and flat transversely with an abruptly rounded lateral dorsal margin. SGP arched transversely (Text-fig. 3), genitalia (Text-fig. 2).

$A$. canifrons females are not readily separable from those of the closely related A. rufipes sp. n., described below. Males, however, are easily distinguished both on the basis of coloration and the form of the genitalia (see further discussion under A. rufipes).

Distribution. Widely distributed through forest areas of the Oriental region and Indonesia, extending into Queensland, Australia (map, Text-fig. 9).

VARIATION. Populations in southern India, Ceylon and Queensland are more usually dark-pubescent, although considerable variation may be noted between individuals within any one population in this respect. One female specimen from Queensland (lectotype of $P$. pluto Turner) has particularly divergent lower orbits and a relatively wide clypeus. The shape of $\mathrm{SMC}_{2}$ and $\mathrm{SMC}_{3}$ is also distinct from that of other populations; however, the male genitalia accord well with those of 
other populations examined. There seem to be no good grounds for separating this peripheral population.

Biology. A female from southern India, Nilgiri Hills, 3500', collected by P. S. Nathan during April I949, is pinned with its spider prey, an adult female Ctenus sp. (Ctenidae).

\section{MATERIAL EXAMINED.}

Pompilus canifrons Smith, holotype ㅇ, Sumatra (Sir Stamford Raffles) (BMNH).
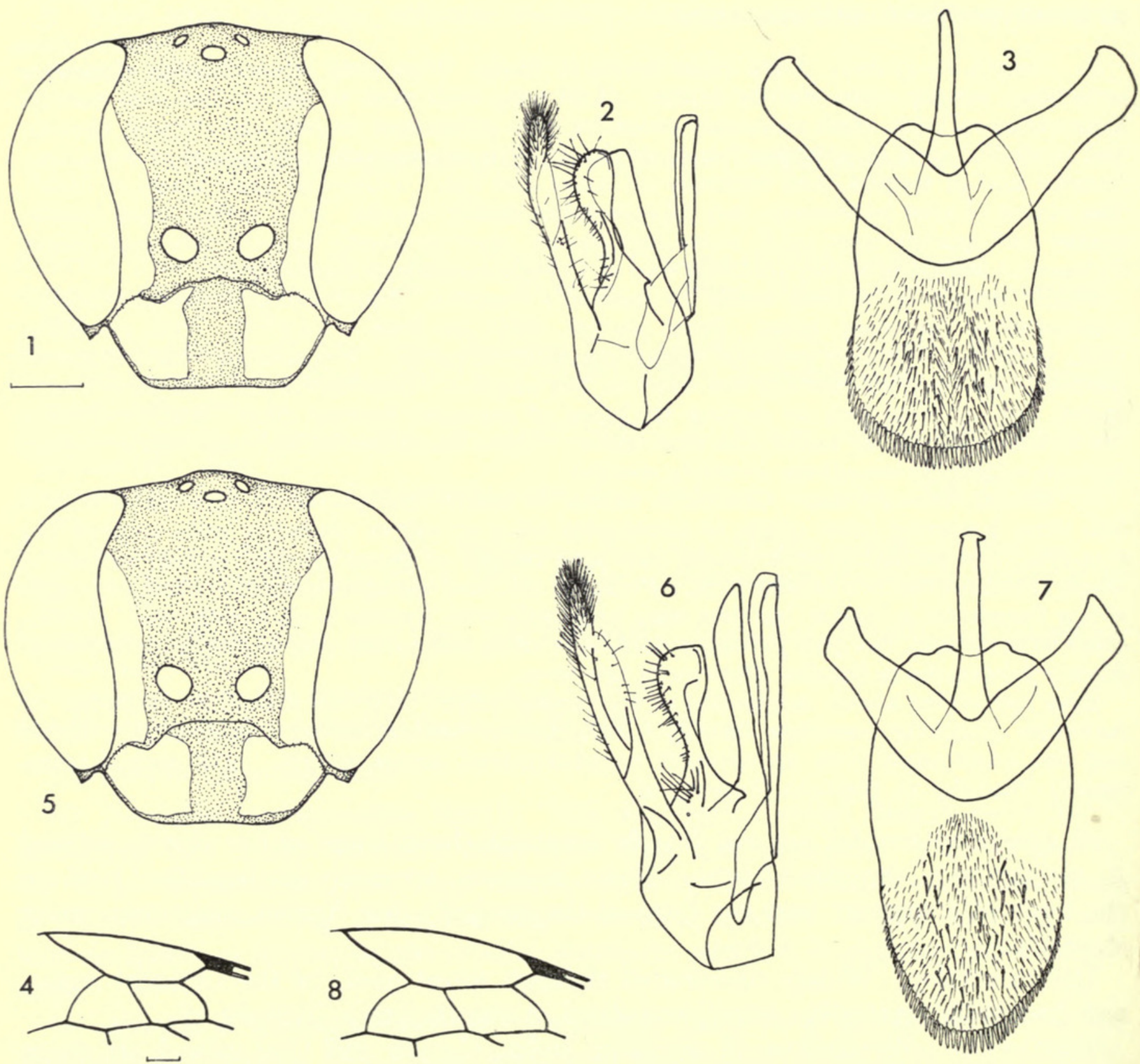

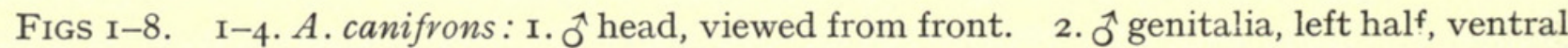
view. 3. $\hat{\sigma} \mathrm{SGP} .4$. $9 \mathrm{SMC}_{2}$ and $\mathrm{SMC}_{3}$ of forewing. 5-8. A. rufipes: 5 . $\mathrm{o}^{t}$ head, viewed

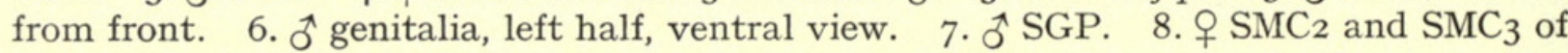
forewing. Scale: I, scale line $=0.5 \mathrm{~mm} ; 2,3,5^{-7}$, same scale; 4 , scale line $=0.5 \mathrm{~mm}$; 8 , same scale. 


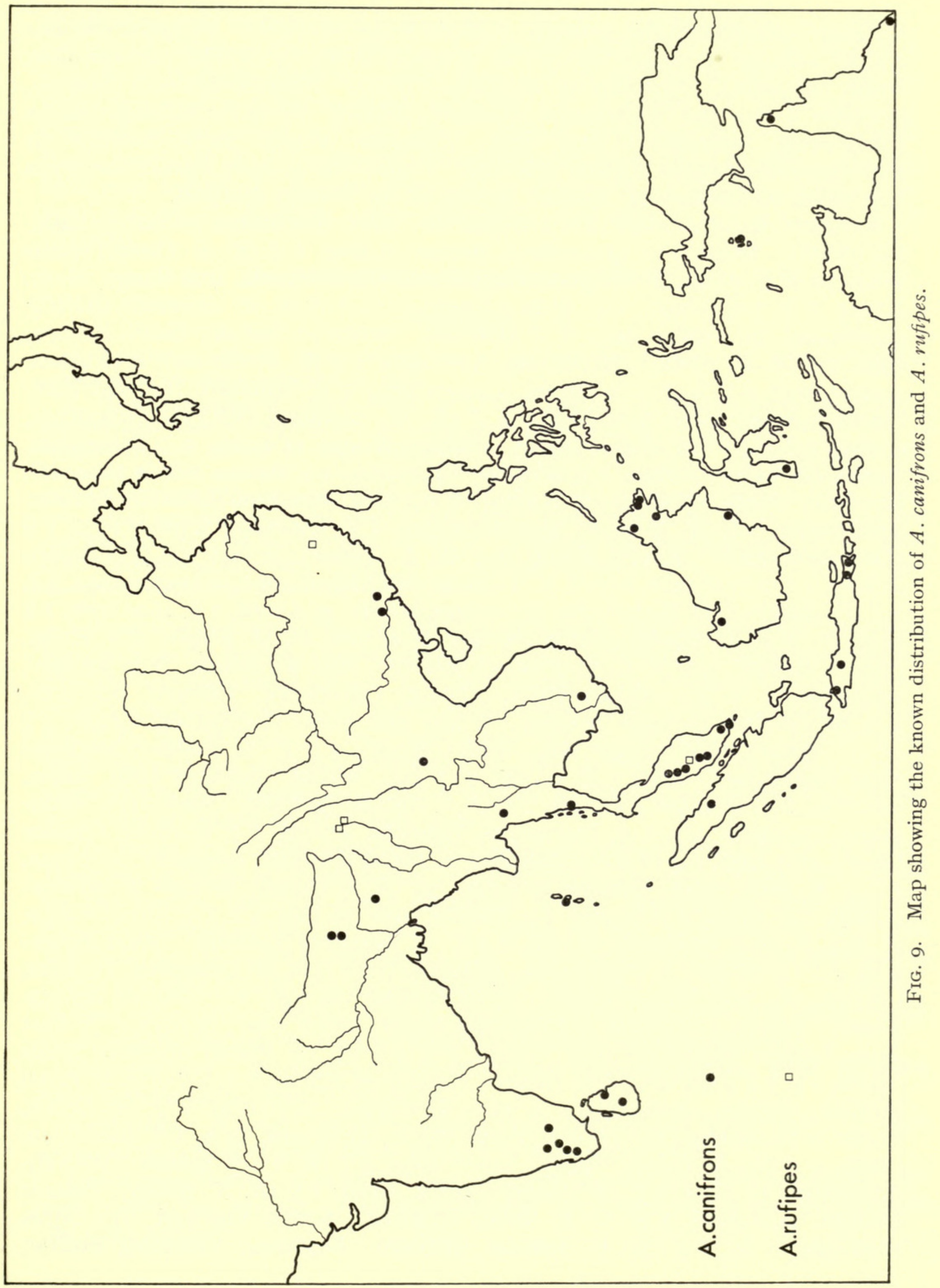


Pompilus leucopheus Smith, holotype ô. West Malaysia (UM). Pompilus limbatus Smith, holotype ô. Sulawesi (A. R. Wallace) (UM). Pompilus nigrocaeruleus Smith, lectotype , Sulawesi (A. R. Wallace) (UM). Pompilus ignobilis Saussure, lectotype + , Ceylon: Trincomalee (Humbert) (MHN). Pompilus rufounguiculatus Taschenberg, holotype 앙 Java (ZM). Pompilus atropos Smith, holotype 우, Sumatra (Sir Stamford Raffles) (BMNH). Psammochares pluto Turner, lectotype ㅇ, Australia: Queensland, Mackay, iii.I897 (R. E. Turner) (BMNH).

ANDAMAN IsLands: I877? , I ㅇ, I $\widehat{o}(\mathrm{BMNH})$. ARU: Aru Islands (no further data), I 우 (ANIC). Australia: Queensland, Mackay, ii.I899, I ô (R. E. Turner) (paralectotype of $P$. pluto); North Queensland, Cape York Peninsula, Iron Range, 26-3I. v.I97I, I 우 I-9.vi.I97I, I 우 27.iv-4.v.I973, 2 ㅇ, 2 ô (S. R. Monteith) (ANIC); Queensland, no further data, I ơ (BMNH). Bonneo: 'Sabah', Bukit Kretam, I952, I ơ (J. D. Hedley); Mt Matang, 5.xii.I9I3, I 우 (G. E. Bryant); Kalabakan, 3-Ir.iv.I973, 2 ㅇ, 2 ơ; Ulu Dusun, I2-22.v.I973, I ơ; Kinabalu National Park, Poring Springs, I60o', 6-Io.v.I973, I $\widehat{o}(K$. M. Guichard) (BMNH); Samarinda, iv.I937, I 오 I ô (M.S. Walsh) (MCZ). BuRma: Mergui, I2.v.I890, I + $;$; Tenasserim, Thaungyin Valley, iii.I890, I ơ; xii.I892, I o ; v.I893, I o + ii.I894, I 우 ix.I894, I o ; Haundraw Valley, viii.I894, I 우 ; ix.I894, I ㅇ, I ô (C. T. Bingham) (BMNH). CEYLon: Trincomalee, 2 우 (H. Humbert) (paralectotypes of P. ignobilis); Kandy, I932, I 우 (Lavavoire) (MHN); Kandy, ii.I903, I ô (R. E. Turner); iii.IgIo, I + (E. Comber);

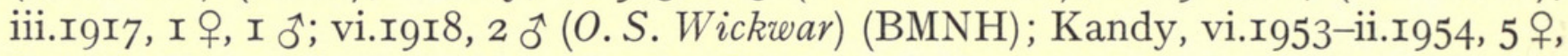
8 ô (F. Kaiser) (coll. Wahis); Kandy, Udawattekelle, 27.x.I966, I 우 I6.xi.I966, I 우 (J. F. G. \& T. M. Clarke) (USNM); Kandy, 25.xi.r929, I (E. Enslin) (ZM, Halle). China: 'Howlik', I ㅇ (R. C. L. Perkins) (BMNH); East Kwantung, 'Yim Na San', II.vi.I936, I 우 (L. Gressott) (MCZ). India: Coimbatore, Valharai, 6.x.-2.xi., 5 우 Nilgiri Hills, Gudalur, iv.I949, 3 우 (one with prey); Cherangode, v.I950, 3 우

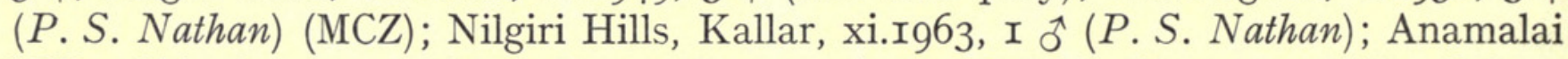
Hills, Chinchona, v.I962, 3 o ; v.I969, I ô (coll. Wahis); Shevaroy Hills, Salem, 6.ix.I934, I ơ; Siruvani, 5.vi.I937, I ô (P.S. Nathan) (BMNH); Coimbatore, Muthikolam, ix-X.I938, I + 3 §ै; Travancore, Tenmalai, x.I938, I oే; Burliyar, Coonoor Ghaut, I7.iv.I937, I ô (BMNH Expedn to S. India) (BMNH); Bangalore, 28.v.I920, I ㅇ (T. R. Bell); Assam, Shillong, ix-X.Ig03, 2 우 (R. E. Turner); Sikkim- 'N. Sikkim', iv.I894, 2 ㅇ; v.I894, I +; ix.I894, I +; Tukvar, 4000', iv.I894, 4 오, I ơ; Runjit Valley,

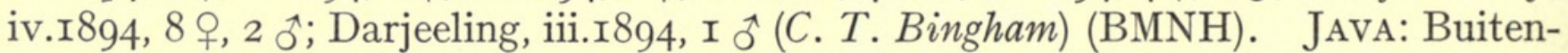
berg, 2 ㅇ, I $\widehat{o}$ (ex R. C. L. Perkins coll.) (BMNH); West Java, Mt Djampang, Tjigaeha, i-ii.I938, 2 ㅇ, I ơ; Salatri, i.I938, I ㅇ; Mt Tjioeng, viii.I937, I đ; Gunung Malang,

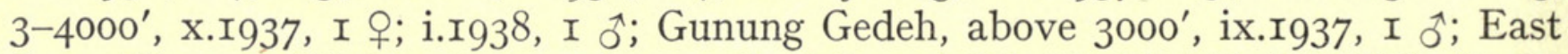
Java, Tengger Highlands, 400o', v.I938, 6 ㅇ, 4 ơ (K. M. Walsh) (BMNH); Soeka Boemi, I ㅇ, I ô (IRSNB); Idjen Plateau, Blawan, 26.vi.I939, I 오 I ô (J.v. $d$. Vecht) (NMSR); Blawan, 26.vi.I939, I ㅇ, I ô; Kalisengon, 28.vi.I939, I 하 Mt Gedeh, Tapos, I-I6.viii.I936, I oै (J.v.d. Vecht) (MCZ); Tjzngsana, I936, I o ; Bileidjilan, i.I937, I ô (M. S. Walsh) (MCZ). LAos: I9I8, I 우 (R. V. de Salvaza) (BMNH). SingaPore: I3 ㅇ, 22 o (C. F. Baker) (USNM, MCZ); I 우 (H. N. Ridley); Botanic Gardens, 25.vi.I926, I ô (C. B. Kloss) (BMNH). South Vietnam: Tay Ninh, II.xi.I924, I 오 I ô (R. V. Salvaza) (IRSNB). Sumatra: Pematang Siantar, 
I6.viii.I930, I 울.iv.I93I, I 우 I9.ii.I932, I ㅇ (R. I. Nel) (BMNH). Sulawesi: I 우 (A.R. Wallace) (paralectotype of P. nigrocaeruleus) (UM); near? Makassar, I ô (A.R. Wallace) (BMNH). West Malaysia: Kedah, iii-iv.I928, 3 ô; Penang Hills, 27.v.I955, I ơ; 8.ii.I959, I 우 6.ii.I96I, I 우 3.xii.I964, I 우 2.viii.I966, I oే; Gombok, 20-26.vi I928, I ․, 2 oै (H. T. Pagden); Selangor, 27.i.I933, I đૈ; Bukit Kutu, 3300', I ơ (A.R. Sanderson); Sungei Pomsom, 2.ix.I928, I đో; Kuala Pomsom, 29.iii.I929, I 우 (H. T. Pagden); Batu Caves, 2I.vi.I928, I $\sigma^{\Uparrow}$ (Miller); Perak, 23.iv. I96r, I 우 (H. T. Pagden); Johore, Lombong, I9.xi.I967, I 우 2 ơ (C. G. Roche) (BMNH).

\section{Anoplius (Orientanoplius) rufipes sp. $\mathrm{n}$.}

(Text-figs 5-8, 9)

ㅇ. Length $\mathrm{I} 4^{-\mathrm{I}} 7 \mathrm{~mm}$. Falls within the range of morphological and colour variation exhibited by $A$. canifrons Smith (p. 383).

o. Length II-I6 mm. Dark brown to black. Yellow coloration margins inner orbits, extends over most of clypeus save a median dark area, marginal streak adjacent to orbit on temples, ventral surface of scape and posterior margin of pronotum. Some yellow-orange ventrally on fore and mid coxae, and outer surface of fore tibia and tarsus. Distal part of mid femur, most of hind femur, mid and hind tibiae, and mid tarsi, reddish orange. Face, and thorax laterally, ventrally, and on propodaeum extensively silvery-pubescent, also coxae and femora. Tergites one to three wholly grey pubescent, tergites four to seven black pubescent. Morphologically very similar to $A$. canifrons Smith (p. 383). SGP strongly folded transversely (Text-fig. 7), genitalia (Text-fig. 6).

I am unable to discover any consistent characters by which to separate $A$. canifrons females from the females I associate on the basis of spatial and temporal coincidence with the males described above. The West Malaysian populations of the two species exhibit a noticeable difference in the relative proportions of $\mathrm{SMC}_{2}$ and $\mathrm{SMC}_{3}$ (Textfigs 4,8 ); this character is, to a more limited extent, apparent also in the males. However, regional variation produces a marked intergradation in this and other characters in the Burmese populations, the females of which I have identified purely on a basis of coincidence with their males.

The males are readily separated by coloration and the form of the genitalia. However, the range of morphological variation reflects the situation described above for the females; although minor differences may be discerned for geographically close populations of the two species, no wholly reliable morphological differences hold good for the entire geographical range. For example, the relative proportions of the face give reliable identification in West Malaysia (Text-figs I, 5). However, in most other parts of its range, $A$. canifrons males approximate much more closely to $A$. rufipes (Text-fig. 5) than to their own West Malaysian populations.

Distribution. At present known only from highland Burma, West Malaysia and southern China (map, Text-fig. 9).

VARIATION. A single male from Nan Ping is considerably larger than the other male paratypes, all of which fall between II and I3 $\mathrm{mm}$ in length.

One female (Burma, I2.xi.I938) has a teratological malformation of the right-hand side of the head capsule. One male (Burma, 29.vii.I938) has a malformation of the right antenna. 


\section{MATERIAL EXAMINED.}

Holotype ${ }^{\wedge}$, Burma: Nam Tamai Valley, E. $97^{\circ} 48^{\prime}$, N. $27^{\circ} \cdot 48^{\prime}, 35^{\circ} 0^{\prime}$, I2.ix.1938 (R. Kaulback) (BMNH).

Paratypes. Burma: Nam Tamai Valley, E. $97^{\circ} 48^{\prime}$, N. $27^{\circ} 48^{\prime}, 3500^{\prime}$, I2.ix.I938,

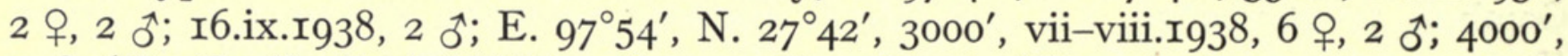
I 우 (R. Kaulback) (BMNH). CHINA: Nan Ping? ('Yen-ping'), 9.vii.I9I7, I 우 6.viii.I9I7, I ô; Io.viii.I9I7, I + (coll. Wahis). West Malaysia: Pahang, Cameron Highlands, Ginting Kial, 5200', I8.vii.I938, 5 ㅇ, I $\sigma^{\uparrow}$ (ex coll. Federated Malay States Museum) (BMNH).

Non-paratypic material. West Malaysia: Pahang, Cameron Highlands, 480o', 6.vi.I935, I ㅇ; 5000', 20.vi.I938, I 우 Selangor, Bukit Kutu, iv.I9I5, I 우 (ex coll Fed. Malay States Mus.) (BMNH); Selangor, 3.ii.r930, I ㅇ (H. T. Pagden) (BMNH).

\section{THE MOROSUS-GROUP}

ㅇ. Dark brown or black with more or less red-brown coloration; wings substantially yellow*

๙ิ. Head as broad as high, antennae only slightly crenulate, genitalia with basal hooklets present, single.

Ethiopian region.

\section{Anoplius (Orientanoplius) morosus (Smith)}

(Text-figs I0, I3, I6, I9-2I)

Pompilus morosus Smith, I855 : r4o. LECTOTYPE $q$, South Africa (BMNH), here designated [examined].

Pompilus elongatus Ritsema, I874 : I88. Holotype $\hat{\jmath}$, ZAIRE? ("Neder-Guinea”) (RNH) [examined]. [Junior secondary homonym in Pompilus of Anoplius elongatus Lepeletier, 1845.] Syn. n.

Pompilus ritsemae Dalla Torre, 1897 : 316. [Replacement name for Pompilus elongatus Ritsema, I874.] Syn. n.

Anoplius morosus (Smith); Arnold, I937: 64; 우, ㄲ.

Africanoplius aciculatus Haupt, I950 : 43. LECTOTYPE $\widehat{\sigma}$, RHodesia (NMSR), here designated [examined].

Africanoplius decoratus Haupt, I950: 44. LECTOTYPE $\widehat{\jmath}$, TANZANIA (MNHU), here designated [examined].

Africanoplius morosus (Smith); Haupt, 1950 : 46; 우.

Africanoplius analis Haupt, I950 : 46. Holotype + , MozambiQue (ZMH) [examined]. Syn. n. [Africanoplius apicalis (Haupt) sensu Haupt, 1950 : 45; $\widehat{0}$. Misidentification.]

\section{LECTOTYPE DESIGNATIONS.}

(I) Pompilus morosus Smith. The supposed holotype female in the collections of the BMNH bears a circular red-edged 'holotype' label and a label in Smith's handwriting, 'morosus type Sm'. However, the locality ('Angola') and the date of accession (' 1873 ') borne by this specimen indicate that there has been a substitution of specimens subsequent to publication of the original description. One female in the collections bears data compatible with that published in the description, viz. 'Port Natal', and with an accessions date ('I849') prior to the date of description. This specimen has been labelled and is here designated lectotype. 
(2) Africanoplius aciculatus Haupt. Haupt proposed A. aciculatus as a new name for males which he had not seen but which he believed Arnold (I937) had incorrectly identified as A. morosus. The number of possible syntypes is uncertain, since Arnold did not label or date all specimens seen and determined by himself. However, I have labelled, and here designate as lectotype, a male specimen of $A$. morosus which was collected by Arnold in person, and which was certainly before him when he described the male of $A$. morosus; the specimen is deposited in the Rhodesian Museum, Bulawayo.

(3) Africanoplius decoratus Haupt. Haupt states in a footnote to the key couplet in which he described $A$. decoratus that the syntypes ('Typen') are part of the material from 'Nyassa-see' determined as A. morosus in the collections of the MNHU. In the same key, he states that the male of A. morosus is unknown. I have seen two female and seven male specimens from Berlin, all of which bear the same data. Firstly, a blue card locality label 'Nyassa-see', with various dates. One female and one male specimen bear labels with the complete binomen 'Pompilus morosus Sm.', the remainder simply 'morosus'. Of the seven males (all A. morosus), I have labelled and here designate as lectotype the specimen that corresponds most closely with the figure given by Haupt (I950:44), which is, however, erroneous in some respect for all the specimens; this is attributable to poorly angled incident lighting during drawing.

ㅇ. Length 10-22 mm. Black; head, prothorax, mesoscutum (save a narrow anterior median black streak), scutellum, metanotum, sixth tergite, apical part of femora, tibiae and tarsi, light or dark red-brown. Antennae orange or light red-brown. Wings yellow, with an apical infuscation (Text-fig. Io) which just invades the tip of the marginal cell. Face beside and beneath antennal insertion sometimes with silvery pubescence, elsewhere brownish black or black.

Apical margin of clypeus feebly to markedly concave, inner orbits converging above, converging below in smaller specimens, normally subparallel or slightly diverging in large examples. MID varying from 0.50 to $0.57 \times \mathrm{TFD}$. POL and OOL subequal. Posterior pronotal margin nearly always distinctly angulate (Text-fig. I3). Propodaeum as broad as long, evenly rounded, sometimes with slight flattening on the declivity. Fore basitarsus with three comb-spines, often twice as long as median thickness of segment bearing them. Larger individuals have an additional short or normal length spine. $\mathrm{SMC}_{3}$ narrowed above, normally much shorter on radial vein than is $\mathrm{SMC}_{2}$.

c. Length $9 \cdot 0-14.5 \mathrm{~mm}$. Coloration similar to female, except red-brown areas lighter, almost yellowish in some individuals, particularly adjacent to orbit and temple. Posterior pronotal margin with yellow transverse band. Fore femora more extensively red-brown, mid and hind tarsi dark brown. Ocellar area black, often two small black areas on front above antennal insertion. These areas extend and may become confluent in small specimens. Mesonotum red-brown with narrow anterior black streak. Apical infuscation of fore wing invades $\mathrm{SMC}_{3}$, most of marginal cell, part of $\mathrm{SMC}_{2}$ and third discoidal cell. Apical tip and hind margin of hind wing also infuscate. Pubescence as in female, but often with some silvery pubescence on fore coxae, also on mesosternum and part of mid coxae.

$\mathrm{SMC}_{3}$ of fore wing narrowed above, distinctly shorter on radial vein than SMC2. Area of $\mathrm{SMC}_{3}$ approximately equal to that of SMC2. SGP (Text-fig. 20) weakly arched transversely, normally arcuate at tip, but occasionally truncate. Genitalia (Text-fig. 2r).

Although previously confused with females of A. nigripes (p. 396), A. morosus females are readily separated on the basis of the characters given in the key to 
species. Arnold (I937) recognized the male, but Haupt (I950) failed to do so; Arnold (I952; I955) placed $A$. aciculatus and $A$. decoratus in the synonymy of $A$. morosus.

Anoplius morosus var. umtaliensis de Saeger, I945: II4. This nomen nudum had two female specimens cited as examples. I have seen these specimens; they are females of Anoplius (Anoplius) aethiopicus Arnold, I937.

Distribution. Widely distributed through woodland and savanna areas of tropical Africa from Senegal to South Africa (map, Text-fig. I9).

VARIATION. This species exhibits very little colour variation, in contrast to its two mainland African congeners and its very near relative in the Madagascan fauna. Most morphological variation appears to correlate with absolute size. However, two females from Sao Thomé Island exhibit morphological and colour differences srom the mainland populations. There is a development of red-brown coloration on the fore and mid coxae and the mesopleuron, and the fore wing has a larger area of apical infuscation, approaching the normal pattern of the males. $\mathrm{SMC}_{3}$ is longer on the radial vein than is $\mathrm{SMC} 2$, as in A. nigripes (Text-fig. II); otherwise, the Sao Thomé population has the characters of $A$. morosus. Males are not yet known from this population, which is very distinctive.

Biology. C. F. Huggins took a female of A. morosus in a cleared area adjacent to part of the Kakamega Forest, western Kenya, on 20 January, I972, together with an adult female Lycosid spider of the genus Pardosa. The paralysed prey was being dragged across the ground by the spider-wasp, which was walking backwards. No more detailed observations were made. I have seen females of this species at Nova Lisboa in Angola, searching actively amongst ground vegetation in Brachystegia woodland, and entering crevices in the ground, particularly some exposed by the uprooting of a fallen tree. A female was also observed searching on the vertical surface wall of a man-made trench in Nova Lisboa. Both sexes have been taken at flowers drenched by the spray of the cataract at Victoria Falls, in conditions which simulated heavy rainfall, except that the sun was shining brightly.

\section{Material examined.}

Pompilus morosus Smith, lectotype + , South Africa: Durban ('Port Natal'), 'Purchased of Stevens, I849. Probably collected by Gueinzius.', no further data (BMNH). Pompilus elongatus Ritsema, holotype $\hat{0}$, ZAIRE? ('Neder-Guinea'): 'Congo, Piaget' (RNH). Africanoplius aciculatus Haupt, lectotype $\widehat{0}$, RHODESIA: Hope Fountain, 5.ii.I922 (G. Arnold) (NMSR). Africanoplius decoratus Haupt, lectotype ${ }^{\star}$, TANZania: Langenberg, iii.-iv.I898 (Fulleborn) (MNHU). Africanoplius analis Haupt, holotype 9 , Mozambioue: Rikatla (Junod) (ZMH).

Angola: 'Angola' ( $J . J$. Monteiro), no further data, I 9 (supposed type of $P$. morosus); Rocadas, west bank of R. Cunene, in Malaise trap, 2I.ii.I972, 2 ô; near Mt Moko, I2 miles S.W. of Luimbale, 5500', on flowers of Compositae by stream, 2I.iii.I97.2, 2 क; Nova Lisboa, Chienga, in Brachystegia woodland, 23.iii.I972, 2 우 (BMNH Southern African Expedn I972) (BMNH); Dundo, xi.I948, I o ( $A$. de 
Barros Machado) (MRAC). Congo (BRazzaville)?: 'Congo', I896? I 9,3 o $^{\star}$ (Dybowski) (MNHN). Ethiopia: Higo Samula, 30.x.I9II, I $o^{*}(R$. J. Stordy); Harrar, I9I2, I 우 (G. Kristensen); Akaki, 8.ii.I948, I ㅇ, I ô; Asba Tafari, 780o', 2.ix.I945, I oै (K. M. Guichard) (BMNH); Bahar Dar, 4.vii.I965, I o (A. E. Gurney) (USNM). Gabon: Libreville, I898, I o (Chalot) (MNHN). Gambia?: 'Gambia', no further data, 2 ô (ex F. Smith coll.) (BMNH). Kenya: Ukumbangi, Nzoi, i-ii.I889,

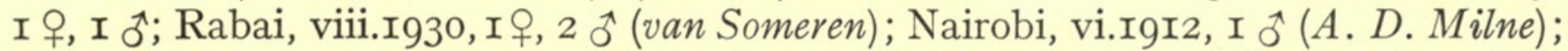

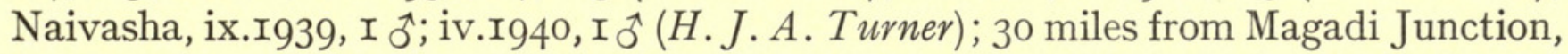
iv.I9I2, I ô (F. G. Hamilton); Kibwezi, viii.I932, I ô (McAvthur); Kwali Forest, 20 miles W. of Mombasa, I.vi.I948, I ㅇ (M. Steele); Kakamega Forest, 34 $53^{\prime}$ E., $0^{\circ}{ }^{\prime} 4^{\prime}$ N., 20.i.I972, I 우 with prey (C. F. Huggins) (BMNH); Tiwi, ix.IgII, I ot (Allaud \& Jeannel); Nyeri, 8.v.I922, 2 ô (A. Seyrig) (MNHN); Tama River, I892 (Chanler Expedn) (USNM). MalawI: Mlange, xii.IgI2-ii.IgI4, 40 ㅇ, 35 oే; Shire Valley, I.viii.I9I3, 2 ô; between Fort Mangoche and Chikala Boma, iii.I9Io, I o; S.W. of Lake Chilwa, I6.i.rgr4, I +; 'S.W. shore of Lake Nyasa', ii.rgro, I ô (S. A. Neave) (BMNH). Mozambioue: Kola Valley, east of Mt Chiperone, I700', 2I.xi. I9I3, 7 우, II ô (S. A. Neave); Beira, I2.x.I939, I đే; (BMNH); Delagoa, Rikatla. I $\hat{\sigma}$ (Junod) (so-called 'allotype' of A. apicalis Haupt) (ZMH); Salone, 25.x.I957, I $\widehat{o}$ (NMSR); Lourenço Marques, i.Igog, I ㅇ (Junod); Pungwe Bay (=Beira?), viii.I903, I oै (P. Krantz) (TM); Chimoia, I928, I ô (P. Lesne) (MNHN). Nigeria: Ibadan, 4.vii.I947, 2 우 20.vii.I95I, I 우 (J. T. Davey); Zaria, Samaru, 29.iv.I972, I 우 (J.C. Deeming); Umudike, I2.iv.I95I, I $\widehat{o}(J$. L. Gregory) (BMNH). RHodesia: Salisbury, ii-iv.I900, 2 오 I oै (G. A. K. Marshall) (BMNH); I 의, same data (NMSR); Victoria Falls, 3o.iv.I972, 2 오 I ô (M. C. Day) (BMNH); Bulawayo, 3o.xi.I9I9, I 우 (G. Arnold) Matetsi, 23.x.I934, I ㅇ (R. H. R. Stevenson); Matopos, I8.xi.I923, I $\hat{o}$ (NMSR). RWANda: I952, I ㅇ ( $R$. Laurent) (MRAC). SAo Thomé IsLand: 5.xi.I932, I 우 (W. H. T. Tams) (BMNH); I920, I ㅇ (H. Havel) (MNHN). Senegal: Dakar, I905, I 우 I ô (G. Melon) (MNHN). Sierra Leone: Njala, i.I936, I 우 (E. Hargreaves); Manawa, I2.viii.I9I2, I ô (J. J. Simpson); no further data, I ô (BMNH). South Africa: Port St. John, v.I923, I ô; iv.I924, I o ; Natal, Kloof, ix.I926, I oै (R. E. Turner) (BMNH); Natal, Umhlahanga Rocks, v.I955, I oే; Zululand, Mfongosi, xii.Igr6, I o (W. E. Jones) (NMSR); Transvaal, 8 miles W. of Barberton, I3.ii.I968, 2 웅 Natal, Lake Sibayi, I3-25.iii.I968, I ô (D. J. Brothers) (AM); Camperdown, 4.iv.I908, I ô (G. F. Leigh); Ramsgate, 7.v.I97I, I ㅇ (L. Vári) (TM); Durban, I5.iii.I9I5, I $\hat{o}$ (Bridwell) (USNM). SUDAN: 20 miles N. of Mongalla, on boat, 24.xii.I96r, I $\sigma^{*}(J$. L. Cloudsley-Thompson) (BMNH). TANZANiA: 'Nyassa-See', Langenberg, I898-I899, 2 ㅇ; same data, 6 ot (paralectotypes of

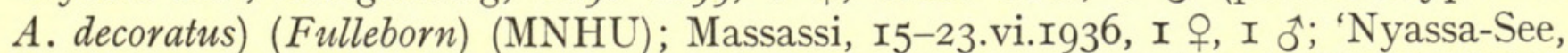
Mbamba-bai', I2-I6.iv.I936, I o; Matengo Hills, I-Io.i.I936, I o (Zerny) (NM). UGanda: Entebbe, ii-vi.I9I3, I3 ㅇ, 4 ô; Bweya, v.I9I3, I 우 4 ô; Mwera, 3I.vii.I9I3,

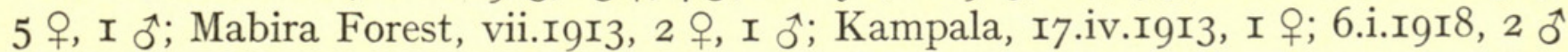
(C. C. Gowdey); west shore of Lake Victoria, Buddu, 3700', ix.I9II, 8 ㅇ, 3 đ̊; valley of Kafu river, xii.IgII, 2 울 Entebbe, vii.IgII, I O; Tero Forest, S.E. of Buddu,

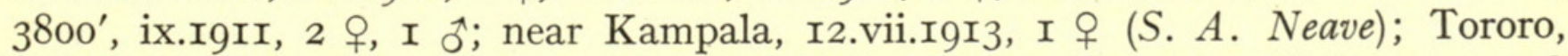
Sukulu, 20.ix.I96I, I 우 (E. Burtt) (BMNH). ZAIRE: Banana, viii-ix.I9I5, 2 우 

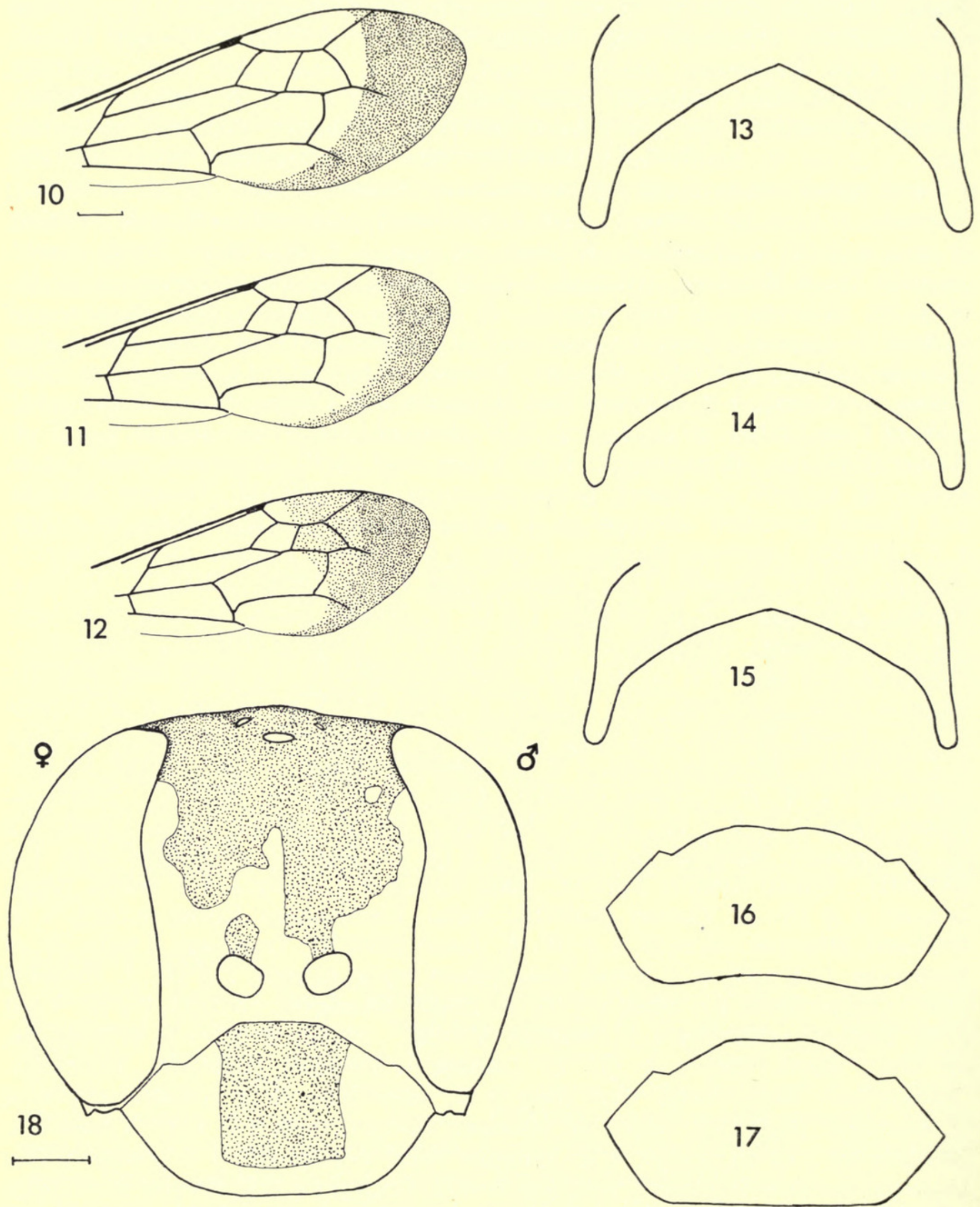

Figs 10-18. Iо-12. 우 fore wing. Iо. A. morosus. II. A. nigripes. I2. A. bifasciatus. I3-I5. Hind margin of $O_{\text {1 }}$ pronotum. I3. A. morosus. I4. A. nigripes. I5. A. bifasciatus. I6, I7. O clypeus. I6. A. morosus. I7. A. nigripes. 18. Gynandromorph individual of $A$. bifasciatus, head in front view. Scale: 10, scale line $=1 \cdot 0 \mathrm{~mm} ; \mathrm{I} 2, \mathrm{I} 3$, same scale; 18 . scale line $=0.5 \mathrm{~mm} ; \mathrm{I}_{3}-\mathrm{r} 7$, same scale. 


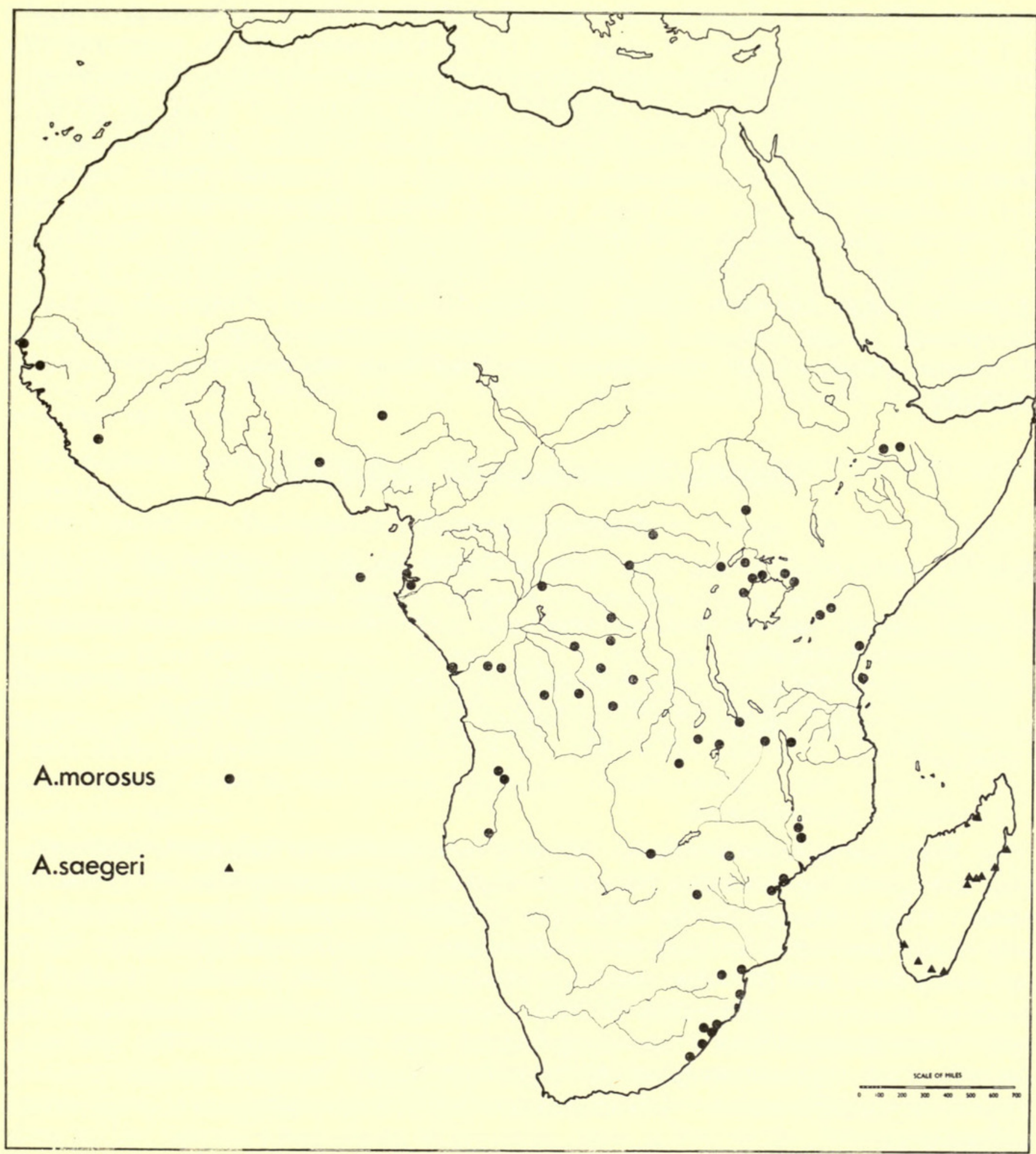

FIG. I9. Map showing the known distribution of A. morosus and A. saegeri.

(Lang \& Chapin) (coll. Wahis); Eala, x-xi.I93I, I ㅇ, 2 o (H. J. Bredo); xii.I932,

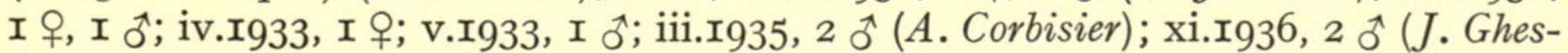
quière); Bambesa, x-xii.I933, 3 우, 2 oิ (H. J. Bredo); Kapanga, xii.I932, I 우, I ô; viii.I932, I ㅇ (F. G. Overlaet); Luluabourg, I8.v.I9I9, I ㅇ (P. Callewaert); 30.i.I963, I 우 (J. Deheegher); Lubumbashi (Elizabethville), iv-v.I923, I ㅇ, I ơ (M. Bequart); iii.I935, I ㅇ (C. Seydel); Kibali-Ituri, 4.x.I93I, I 우 (Mme. L. Lebrun); Ituri, Bunia, 
I938, I $ᄋ$ ( $P$. Lefevre); Lemfu, i-ii.I945, 2 오 I $\hat{o}$ ( $P$. de Beir); Sankuru, 2r.iv.I930, I + (J. Ghesquière); Gandajika, I954, I 우 (P. de Francquin); Djeka, I955, I 우 ( $R$. Roisieux); Kwango, Popokabalaka, ix.I949, I q (L. Dubois); Kwango, Mwilambongo, ix.I949, I 우 (Van der Borght); Katanga, Kasenga, iv.I93I, I $\hat{0}$ (H. J. Bredo); Kabinda, I + (Schwetz); Basoko, iii.I949, I ô (P. L. G. Benoit); Lake Albert, Ishwa, ix.I935, I $q$ (H. J. Bredo); Lomami, Kaniama, I93I, I ô; Congo da Lemba, r.ii.I9I3, I ô (R. Mayné); Kasinga, 20.iii.I93I, I 우 (H. J. Bredo); Kayambo-Dikulwe, vi.I907, I ô (S. A. Neave) (MRAC); Thysville, 25.viii.I950, I ô (M. Leclerq); Kambaye, Lupula, I930, I 우 ( $R$. Colbert) (IRSNB). ZAMBIA: Abercorn, 6.ii.I95I, I 우 $(R$. Albrecht); Upper Luangwa Valley, viii.Igı, I ㅇ, I $\widehat{乛}$ (S. A. Neave); N. of Lake Bangweulu, II.xii.I946, I 우 (BMNH); Abercorn, 22.xii.I943, I 우 (IRSNB).

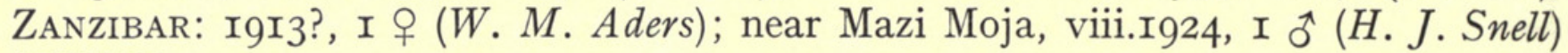
$(\mathrm{BMNH})$.

\section{Anoplius (Orientanoplius) saegeri Arnold}

(Text-figs I9, 22, 23)

Pompilus plebeius Saussure, I89I : 266. LECTOTYPE + , Madagascar (MHN), here designated [examined]. [Junior primary homonym of Pompilus plebejus Dahlbom, I843.]

Pompilus plebejus Saussure; Saussure, I892:365; 우, ㅅ․ [Incorrect subsequent spelling of P. plebeius Saussure, I891.]

Anoplius saegeri Arnold, I937 : 61. LECTOTYPE + , MAdAGASCAR (MRAC), here designated [examined]; type-series given incorrect locality labels, 'Ile St. Thomé'. Syn. n.

Psammochares jocaste Banks, I94I : 357. Holotype +, MAdagascar (ANS) [examined]. Syn. n.

\section{LECTOTYPE DESIGNATIONS.}

(I) Pompilus plebeius Saussure. There is no indication in Saussure's description that this species was described from other than a single female specimen. However, there are eight females in the collections of $\mathrm{MHN}$, of which I regard as syntypes two which bear labels in Saussure's handwriting, 'Pompilus plebejus Ss o.' Both specimens have had the right fore wing removed and glued to a card, possibly to facilitate illustration. Monsieur R. Wahis has labelled the better preserved of the two 'Lectoholotype', and I am in agreement with his selection. The specimen also bears his typewritten label ' $R$. Wahis det. I970. Anoplius saegeri Arn. 우 Type de P. plebejus sauss.' I have also labelled, and here designate this specimen, as lectotype.

(2) Anoplius saegeri Arnold. Arnold gave no published holotype status to any of the three specimens in his type-series. The female and one male bear his red 'type' labels, the second male a paratype label of the type used by the MRAC. The female has been labelled, and is here designated as lectotype.

ㅇ. Length I2-I9 mm. Red-brown; more or less black coloration evident at pleural sutures, articulations of coxae, on postnotum, midventrally on mesosternum (=ventral part of true mesopleuron), anterior face and posterior edge of first tergite and sternite, most of second tergite, rest of abdomen. Yellow coloration posterolaterally on propodaeal rim. Wings yellow, with more or less diffuse infuscation terminally, outside the closed cells. Lower face and 
coxae with sparse silvery pubescence in fresh specimens. Eastern populations more extensively dark coloured.

Apical margin of clypeus concave, inner orbits convergent above, subparallel below. Morphologically very similar to $A$. morosus (p. 389) but frons flatter in larger specimens, more swollen in smaller specimens. Propodaeum higher, with a more direct shallow curve from postnotum to posterior rim when viewed in profile. Thorax as a whole appearing more robust than in A. morosus. $\mathrm{SMC}_{3}$ variable in form, normally as in $A$. morosus, but often more similar to that of $A$. nigripes (Text-figs Io, II).

o. Length 9-14 mm. Red-brown; with more or less black coloration, as in the female. Yellow coloration often borders: inner and outer orbits, mandibular edge, malar space, fore coxa, posterior margin of pronotum, posterolateral rim of propodaeum, often a band anteriorly on third tergite (may be concealed by telescoping of segments). Wings yellow, with diffuse infuscation terminally, often invading outer cells. Silvery pubescence may be extensive on fresh specimens, particularly on face and coxae, but also on pleurae, femora and elsewhere.

Morphologically as A. morosus (p. 389), with slight but constant differences in SGP and genitalia (text-figs 22, 23).

A. saegeri is closely related to $A$. morosus, but readily recognized by its distinctive coloration.

Distribution. Madagascar; this species seems to occupy all the ecological zones on Madagascar which on mainland Africa are occupied by three distinct species (map, Text-fig. I9).

VARIATion. A. saegeri exhibits considerable variation in colour. Female specimens from the drier south-western parts of the island (Tulear, Fort Dauphin, Bekily) show a reduction in the amount of black coloration visible at the thoracic sutures, and the dark area on the mesosternum may be totally absent. The redbrown areas are generally of a lighter shade than is the case with specimens from more 'typical' areas in the central highlands, which conform most closely to the description given.

Specimens from the wet forest area of the east coast are very much darker, with the red-brown coloration replaced by black on the abdomen, propodaeum, and thorax save the prothorax, mesonotum, tegulae and scutellum. The yellow colour on the propodaeal flanges is obliterated. A female of this colour form is holotype of $P$. jocaste. Males reflect this geographical colour variation, but the form of the genitalia remains constant throughout the distributional range.

Certain specimens from the zone around Tananarive exhibit colour patterning which tends from that of the 'typical' populations towards that of the darker forest form. One female from Tzimbazaza, and another from Betongolo, whilst close to the normal colour form of the area, show a loss of the yellow coloration from the propodaeal flanges, and an increase in the amount of black visible at the thoracic sutures. Two other females, from Tananarive and Ankadimanga, also show a development of black colour on the thorax and propodaeum, although the yellow colour is not lost.

The Tananarive populations may themselves be regarded as intermediate between the extreme light-coloured south-western populations and those of the eastern forests.

Colour variability correlates superficially with the patterns of precipitation in the island, but certain exceptions can be noted, for example at Fort Dauphin, 
where the 'typical' form occurs in an area of high rainfall. It seems reasonable to speculate that the prevailing humidity and temperature in the actual nest site, rather than actual rainfall levels, are likely factors controlling the degree of development of dark coloration in this species. A. bifasciatus and A. nigripes on the African mainland also exhibit considerable colour variation of a similar type.

\title{
MATERIAL EXAMined.
}

Pompilus plebeius Saussure, lectotype o, Madagascar: Andrengoloka, no other data (MHN). Anoplius saegeri Arnold, lectotype + , Madagascar: Tananarive (C. Lamberton). Mislabelled 'Ille de St. Thomé '( H. de Saeger)' in error (MRAC). Psammochares jocaste Banks, holotype + , MADAGASCAR: Tananarive, Moramanga district, Oriental forest (C. Lamberton) (ANS).

MADAGASCAR: no other data, 4 ô (F. Sikora) (MHN); 2 우, (ex coll. E. Andre)

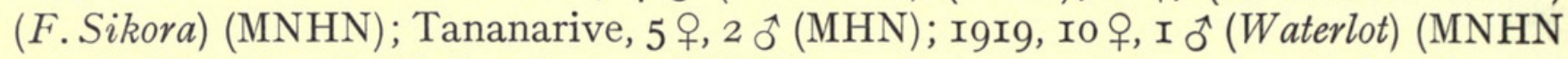

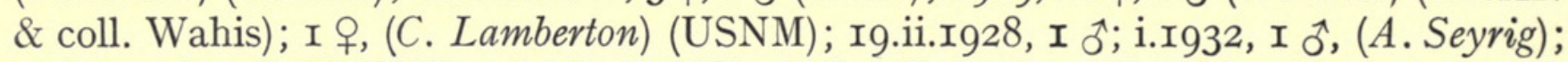
Io.iv.I948, I 9 (MNHN); mislabelled 'Ile de St. Thomé' - collected at Tananarive by C. Lamberton, 2 oै (paralectotypes of $A$. saegeri) (MRAC); 30.iv.I968, I + (K. Guichard) (BMNH); Tzimbazaza, 8.viii.I950, I ㅇ; 24.ix.I950, I ㅇ (R. Benoist) (MNHN); vii.I950, I 오, I ơ; i.I952, 5 우 6 ơ (R. Benoist) (MRAC \& coll. Wahis); Andrengoloka, no other data, I 9 (paralectotype of $P$. plebeius), I o (MHN); Betongolo, xii.I947, 2 우 (P. Clement) (MNHN); Ankadimanga, xii.I957, I 우 (Jean-Elie); Andramasina, I93I, I 우 (Lasere); Ambatolampy, I93I, I 우 (Lasere); Bekhara, iii.I937, I ô $(A$.

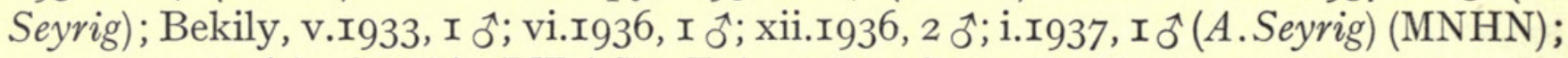
v.I942, I 우 (A. Seyrig) (MRAC); Tulear Province, Bevilany, I00o', I2.iv.I968, I 오 I ô (K. M. Guichard) (BMNH); Fort Dauphin, I5.iv.Ig68, I 오 I ô (K. $M$. Guichard) (BMNH); I936, I ㅇ (A. Seyrig) (MNHN); Analahava, I906, I 우 (J. Descarpentries) (MNHN); Rogez, i.I933, I ô (Seyrig) (light colour form); iii.I935, 2 के; ii.I944, 5 ô (Seyrig) (dark colour form); Fito, v.I932, I ô (Seyrig); Marovato, xii.I943, I + (Abadie) (MNHN); Rogez, Analandraraka, vi.I937, 2 ㅇ, 2 ô (Seyrig) (MRAC); Tamatave, ii.I934, I + (Olsoufieff) (MNHN); Ile Europa, iv.I964, I ㅇ (P. Malzy) (MNHN).

\section{Anoplius (Orientanoplius) nigripes (Haupt) comb. $\mathbf{n}$.}

\author{
(Text-figs II, I4, I7, 24, 25, 29)
}

[Anoplius bifasciatus (Tullgren) sensu Arnold, I937 : 6r; $\widehat{0}$. Misidentification.] [Africanoplius elongatus (Ritsema) sensu Haupt, I950 : 44; శో. Misidentification.] Africanoplius nigripes Haupt, I950:45. Holotype ô, ZAIRE (IRSNB) [examined].

Anoplius morosus bahimae Arnold, I955:359. LECTOTYPE , Burundi (MRAC), here designated [examined]. Syn. n.

\section{LECTOTYPE DESignation.}

Anoplius morosus bahimae Arnold. Arnold did not specify which of three females and a male was holotype; both the male and one female bear his red 'type' labels. I have labelled, and here designate as lectotype, the female which bears Arnold's type-label. 
ㅇ. Length 13-19 mm. Black; at least clypeus, lower face, scapes, temples and occiput dark red-brown, which may extend to most of head, prothorax and legs in some populations. Wings yellow, fore wing with an apical infuscation which does not invade the cells (Text-fig II), rarely enters extreme tip of marginal cell. Pubescence light brown to brownish black, rarely silvery.

Apical margin of clypeus transverse, inner orbits converging above, subparallel below, diverging slightly in larger specimens. MID varies from 0.50 to $0.54 \times$ TFD. POL normally slightly less than OOL. Posterior pronotal margin arcuate, or with an indistinct median angulation. (Text-fig I4). Propodaeum evenly rounded. Fore basitarsus with three combspines, rarely approaching twice as long as median thickness of segment bearing them. $\mathrm{SMC}_{3}$ narrowed above, but normally subequal to $\mathrm{SMC}_{2}$ on radial vein (Text-fig. II).

o. Length ro-I5 mm. Coloration similar to female; red-brown areas of female more frequently brownish yellow in male; median black area on clypeus, black area on frons reaching antennal insertion. Posterior margin of pronotum with yellowish brown transverse band. Patches of same colour on propleura and anteriorly on fore coxae. Otherwise black. Fore wing yellow with an apical infuscation as in $A$. morosus (Text-fig. ro), but occasionally infuscate area reduced. Hind wing with apical area and hind margin infuscate.

$\mathrm{SMC}_{3}$ of fore wing narrowed above, but equal to or distinctly longer than $\mathrm{SMC}_{2}$ on radial vein. $\mathrm{SMC}_{3}$ greater in area than $\mathrm{SMC}_{2}$. Genitalia (Text-fig. 25). SGP (Text-fig. 24) more strongly arched transversely than is that of $A$. morosus, normally truncate apically, but sometimes arcuate.

Females of this species have previously been confused with those of $A$. morosus (p. 388). The male is quite distinctive, however, but has always been regarded as the male of $A$. bifasciatus (p. 400).

Distribution. Central and Eastern Africa (map, Text-fig. 29).

VARIATion. Populations of highland Kenya, Uganda and eastern Zaire are extensively black, with some red-brown only on the face. Females from east coastal and southern populations show a much greater development of red-brown coloration, to the extent that they have always previously been confused with A. morosus females. The black area on the frons is reduced to the area of the ocellar triangle alone, the antennae are red-brown (but never wholly orange), the pronotum, tegulae, dorsal surface of the scutellum, tibiae and tarsi also so coloured. Males are similarly variable; southern populations show a reduction of the black area on the frons and have a red-brown pronotum, the posterior margin of which is frequently yellow. The mesonotum and scutellum also have small red-brown patches. The fore legs and mid and hind tibiae may be more or less red-brown, tending towards brownish yellow. The antennae, save a few terminal segments, develop the colour of the face. There is also a development of silvery pubescence above the clypeus, on the fore coxae, and on the neck and collar of the pronotum.

One female from Amani and one from Mlange exhibit coloration intermediate between the extremes described; the pronotum has some red-brown coloration, but with much black anteriorly. The black area on the frons is extended well beyond the ocellar triangle. The tibiae and tarsi are red-brown, however. One black female from Wawamba has an interrupted band of red-brown on the posterior pronotal margin, as do the lectotype and paralectotype females of A. morosus bahimae. Some females of the dark form have a more extensive apical infuscation of the forewing, approaching in form that of $A$. morosus. 
One male from Mlange shows a coloration intermediate between that of the dark form and that of the southern populations; the black area extends over most of the frons, but not the clypeus. The brownish yellow area of the pronotum is reduced by the encroachment of black areas anteriorly and laterally. The mid and hind tarsi, mesonotum and scutellum are black, also the antennae save the scape, pedicel and first flagellar segment, and ventral portions of the second and third segments.

Three males from Bambesa have rather different genitalia, the digiti volsellari being narrower than those of other populations. The SGP is apically rounded, but this condition is observed in some southern populations also. One of these males has the pronotum black, with a streak of yellow on the posterior pronotal margin.
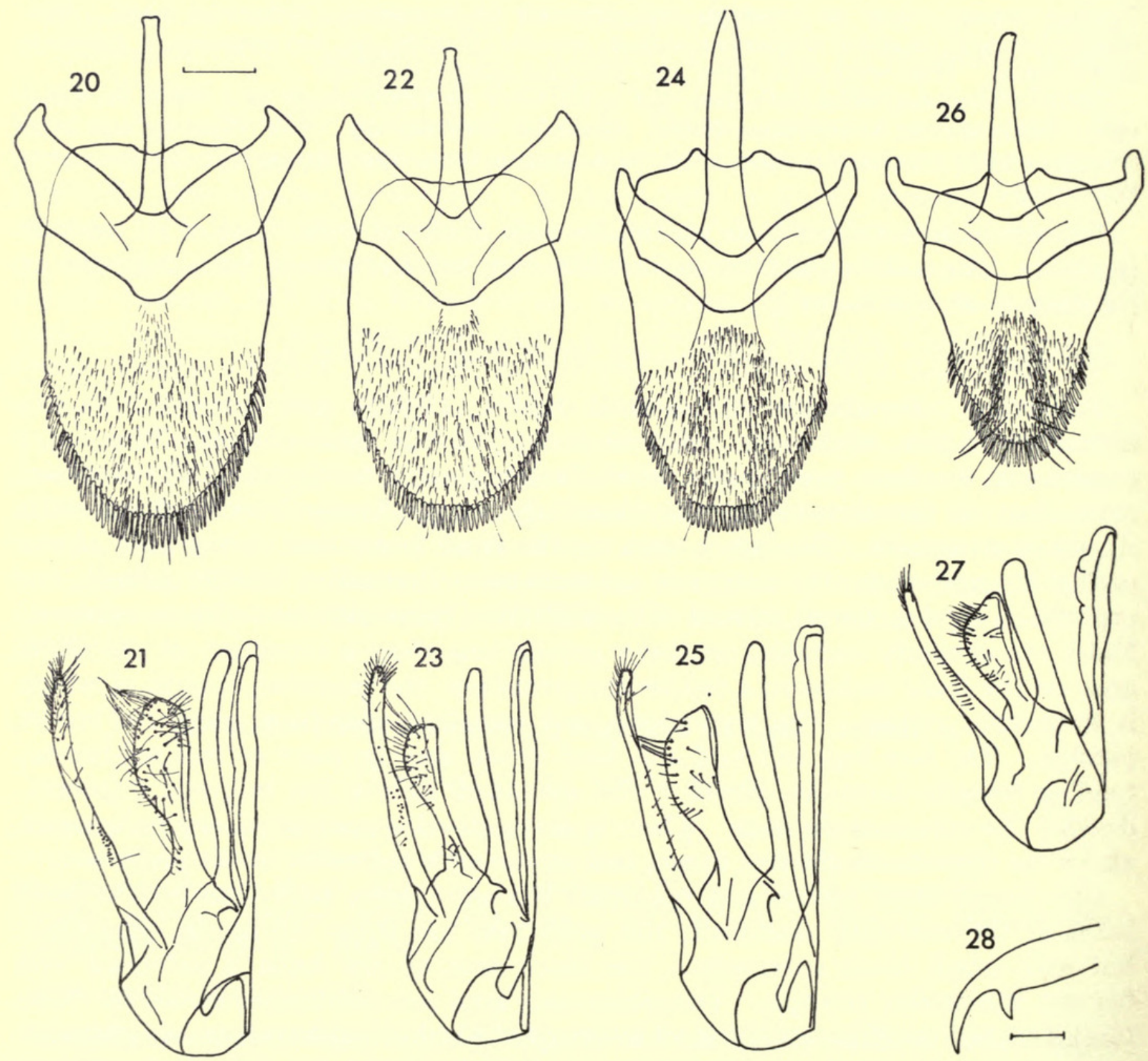

Figs 20-28. 20-27. $\hat{\sigma}$ SGP and $\hat{\sigma}$ genitalia, left half, ventral view. 20, 21. A. morosus. 22, 23. A. saegeri. 24, 25. A. nigripes. 26, 27. A. bifasciatus. 28. A. bifasciatus, $\widehat{0}$ claw. Scale: 20 , scale line $=0.5 \mathrm{~mm} ; 2 \mathrm{I}-27$, same scale; 28 , scale line $=0 . \mathrm{Imm}$. 


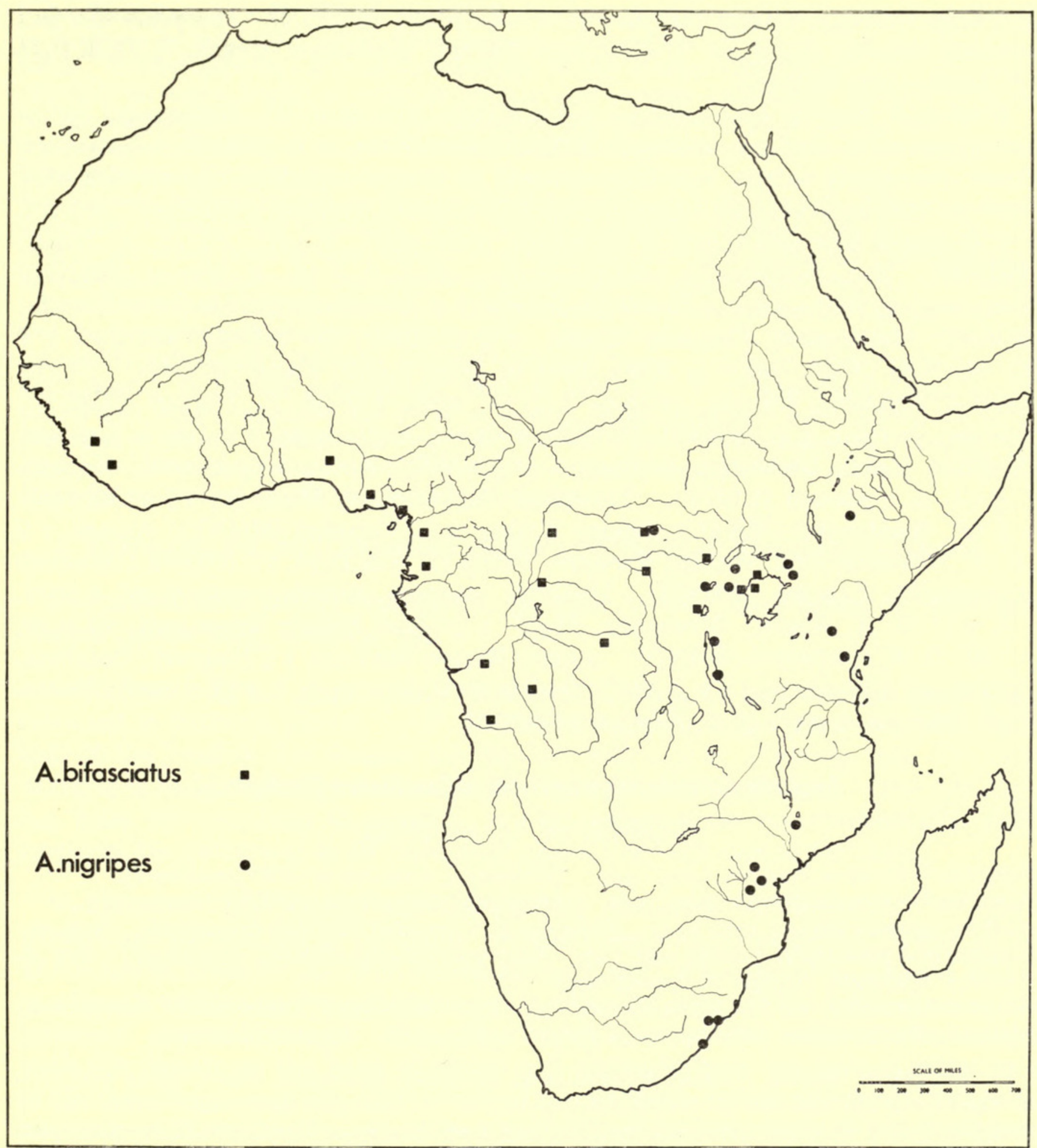

FIg. 29. Map showing the known distribution of $A$. nigripes and $A$. bifasciatus.

Biology. A female of $A$. nigripes in the BMNH collections, taken by the Second Oxford University Tanganyika Expedition in the Kungwe District, bears a label 'Carrying spider in forest'. I have not been able to trace any specimen of prey in the Museum's collections.

MATERIAL EXAMINED.

Africanoplius nigripes Haupt, holotype $\hat{0}$, ZAIRE: Parc Nationale Albert, Lac 
Mugunga-Bulengo, ii.I934 (Mission G. F. de Witte) (IRSNB). Anoplius morosus bahimae Arnold, lectotype ㅇ, BuRundi: Bururi, I800-2000 metres, 5-I2.iii.I953 (P. Basilewsky) (MRAC).

Burundi: Bururi, I000-2000 m, 5-I2.iii.I953, I 우 I ô (P. Basileresky) (paralectotypes of $A$. morosus bahimae) (MRAC); same data, I ㅇ (NMSR). ETHIopIA, Gatelo Amaiya, 4.xi.rgII, I ô; Higo Samula, 30.x.I9II, I ô (R. J. Stordy) (BMNH). KenYa: Malawa Forest, 6.vi.I952, I ô (NMSR); Nandi Plateau, 5700-6200', vi.I9II, I ; s southern foot and slopes of Mt Elgon, 5100-5800', vi.rgIr, I 우 (S. A. Neave) (BMNH). Malawi: Mlange, xii.Igr2-ii.IgI4, 2I 오 8 ô (S. A. Neave) (BMNH). MozAmbique: Chimanimani Mountain, ii.I958, I ô (University of Cape Town Expedn) (NMSR). Rhodesia: Chirinda, ii.I96r, I ㅇ (NMSR); Mt Selinda, xii.I935, I 우 (G. van Son) (TM); Valley of Musa, Iooo m, I905, 2 ô (G. Vasse) (MNHN). South Africa: Zululand, Eshowe, iv.I926, I ㅎ vi. I926, I 우 (R. E. Turner) (BMNH); Eshowe, iv.I960, 2 ô (BMNH, NMSR); Eshowe, I-7.x.I949, I ㅇ (A. L. Capener) (USNM); Natal, Umhlanga, iv.I94I, I ㅇ (NMSR); Natal, Umtentweti, vii.I95I, I ô (A. L. Capener) (USNM). TANZANIA: Kilimanjaro, Marangu, I3-20.vii.I957, I ô (P. Basileresky) (MRAC); Amani, ii.I904, I o (Vosseler) (MHNU); Amani, I o (F. X. Williams) (coll. Wahis); Kungwe, 'Camp II,' 8.ix.I959, I + (Oxford University Tanganyika Expedn) (BMNH). UGANDA: western Ankole, 4500-5000' X.I9II, 2 우 I 조 (S. A. Neave); Wawamba, I895?, I 우 (Scott Elliot); Busongoro, xii.I927, I $\hat{o}$ (G. D. H. Carpenter) (BMNH). ZAIRE: Region des Lacs, I q (Sagona); Bambesa, I5.ix.I933, I oే; 30.x.I933, 2 ơ (H. J. Bredo); Uelé, 30.x.I933, I ơ (J. Leroy); HauteUelé, Abimva, I925, I ô (L. Burgeon) (MRAC).

\title{
Anoplius (Orientanoplius) bifasciatus (Tullgren)
}

\author{
(Text-figs I2, I5, I8, 26-29)
}

Pompilus bifasciatus Tullgren, I904:44I. Holotype ㅇ, Cameroun (NR) [examined]. Pompilus bavinganus Strand, I9I I : 500. Holotype $ᄋ$, CAMERoun (MNHU) [examined]. Anoplius apicalis Haupt, I929: I44. Holotype 9 , 'CAPLAND' (MNHU) [examined]. Syn. n. Elaphrosyron multipictus Arnold, I937: 42. Holotype ô, ZAIRE (MRAC) [examined]. Syn. n. Anoplius bifasciatus (Tullgren); Arnold, r937 : 61; O+.

Anoplius bifasciatus var. ornatus de Saeger, I945: II3. Holotype 0 , ZAIRE (MRAC) [examined]. [Africanoplius elongatus (Ritsema) sensu Haupt, I950 : 43; ㅇ. Misidentification.]

ㅇ. Length $\mathrm{I} 2-20 \mathrm{~mm}$. Black; clypeus, face, antennae, prothorax, coxae, tibiae and tarsi in whole or in part red-brown, the clypeus always so. A line adjacent to inner orbits, line on temple adjacent to outer orbit, and line bordering posterior pronotal margin (often interrupted medially) are frequently pale yellow. Yellow markings occasionally much more extensive, affecting spots on pronotum anteriorly beneath streptaulus, mesonotum, scutellum, meso- and metapleurae, and hind coxa. Wings yellow, with an apical infuscation which occupies $\mathrm{SMC}_{3}$ and most of marginal cell (Text-fig. I2). Lower face, coxae, and often much of pleurae, propodaeum and femora with silvery pubescence, elsewhere black.

Apical margin of clypeus transverse. Inner orbits converging above, parallel below. Face narrow, MID varies from 0.44 to $0.5 \mathrm{I} \times \mathrm{TFD}$. POL and OOL subequal. Posterior pronotal margin obtusely angulate (Text-fig. I5). Propodaeum broader than long, evenly rounded, with very slight flattening on declivity. Fore basitarsus with three combspines, one to two times median thickness of segment bearing them. $\mathrm{SMC}_{3}$ narrowed above, subequal to or shorter than $\mathrm{SMC} 2$ on radial vein. 
๙. Length II-I5 mm. Black, more or less extensively maculated with yellow, which may be bordered by red-brown, particularly ventrally on antennae and coxae, and on femora and tibiae. Yellow coloration at least on mandibles, border of inner orbit on face, and on clypeus, ventrally on scape, border of orbit on temple, spot beneath streptaulus, posterior pronotal margin, propleuron, small median spot posteriorly on mesonotum, small spot on base of mesopleuron, small median spot on first abdominal tergite, and paired spots anteriorly on second and third tergites. Also patches ventrally on fore and mid coxae, and on tibiae. In extreme development, yellow patches on face are confluent across top and bottom of clypeus, malar space and on temple and mandible. Spot beneath streptaulus enlarged, neck and propleuron yellow, additional pronotal spot, mesopleuron with much enlarged patch and additional spot, mesonotum, scutellum and postscutellum, propodaeum with a median and lateral patches (which may be confluent), metapleuron with two patches; first tergite with large spot, second and third tergites with paired lateral patches. All coxae, femora, tibiae, and the fore tarsi extensively yellow and red-brown, mid and hind tarsi black. Extensive silvery pubescence on head, thorax, coxae and propodaeum, dark on abdomen. Fore wing fuscohyaline, faintly tinged with yellow, infuscate apically as in female. $\mathrm{SMC}_{3}$ narrowed above, shorter on radial vein than is SMC2. Genitalia (Text-fig. 27); SGP strongly arched transversely (Text-fig. 26). Parapenial lobes of specimens from western populations longer, more like those of $A$. nigripes (Text-fig. 25) than of the Uganda population figured.

A. bifasciatus is a very distinctive member of the Ethiopian pompilid fauna.

Distribution. Widely distributed through humid forest areas of West and Central Africa (map, Text-fig. 29).

GynANDROMORPH. A gynandromorph individual in the collections of the MRAC, collected at Bokuma (Zaire), by P. Hulstaert, is predominantly female. The right half of the head is also female, but the left half is male (Text-fig. I8). The left antenna is male, the right antenna female, but of male dimensions. The specimen has been left over-long in cyanide, so that yellow areas are substantially pink; however, the pattern of facial coloration agrees well with that of the male.

VARIATION. This species exhibits marked variability in the extent of yellow areas, more particularly in the male. Females also exhibit variability in the extent of red-brown areas on the head, pronotum and legs. The type of $A$. apicalis Haupt is a female with extensive red-brown coloration, but without the yellow line on the posterior pronotal margin. Haupt's identification of the male of A. morosus with this female on the basis of colour and particularly of the area of infuscation of the fore wing, has given rise to much of the confusion within this group of species, and to a proliferation of names. On a basis of known distribution, it seems unlikely that the type of $A$. apicalis was collected at the Cape, and it is probably mislabelled. I have seen specimens similar to the type from Zaire and West Africa.

Arnold also did not recognize the true male of $A$. bifasciatus, and described it in Elaphrosyron as E. multipictus. The facial colour pattern of the gynandromorph described above, and yellow-maculated females (A. bifasciatus var. ornatus de Saeger), together with distributional data, amply confirm the association of sexes here made. Since Arnold failed to appreciate that he had before him males of three species in the morosus-group, he did not seek the true female of the males (A. nigripes) which he mistakenly associated with $A$. bifasciatus. 
MATERIAL EXAMINED.

Pompilus bifasciatus Tullgren, holotype 우, Cameroun: ('Camerun') (Sjostedt) (NR). Pompilus bavinganus Strand, holotype 우 Cameroun: 'Kamerunberg' (Ekona), Bavinga, 22.x.I9I0, 400-600 m (E. Hintz) (MNHU). Anoplius apicalis Haupt, holotype + , 'CAPLAND' (Krebs), no further data, locality almost certainly incorrect (MNHU). Elaphrosyron multipictus Arnold, holotype ô, ZAIRE: Uele, Bambesa, 3o.viii.I933 (J. V. Leroy) (MRAC). Anoplius bifasciatus var. ornatus de Saeger, holotype + , ZAIRE: Uele, Bambesa, 6.vi.I937 (J. Vrydagh) (MRAC).

Angola: Salazar, Field Station of I.I.A.A., on path through dense humid forest, I3.iii.I972, I ô (D. Hollis, BMNH Southern African Expedn I972) (BMNH). CAMERoun: Ebolowa, Nkuemvone, 29.vii.I967, I ô (L. Matile) (MNHN); 'Kamerun', I ㅇ (Conradt) (MNHU). Gabon: 'Gaboon', I ㅇ (Theorin) (NR); Muni, Mts de Cristal, I5-3I.x.I969, I ô (A. Villiers) (MNHN). Liberia: Belleyella, I940, I ô (W. M. Mann) (USNM). Nigeria: Ife-ife, 25.v.I969, I $\sigma^{*}$ (J. T. Medler); Okigwi, 26.v.Igro, I + (J. J. Simpson) (BMNH). Sierra Leone: Njala, I4.xi.I932, I o; vi.r936, I $q$ (E. Hargreaves) (BMNH); Sierra Leone, I ô (A. Afzelius) (NR). Togo: I $ᄋ$, no further data (coll. Wahis). UGanda: Tero Forest (W. shore of L. Victoria), vii.I9I2, 2 ㅇ, I7 ô (C. C. Gowdey) (some paratypes of E. multipictus) (BMNH, NMSR); Tero Forest, S. E. Buddu, 3800', 28.ix.I9II, I ㅇ (S. A. Neave); W. shores of L. Victoria Nyanza, Buddu, 3700', I9-25.ix.I9II, 9 우, 3 ơ (S. A. Neave); Budongo Forest, Unyoro, 3400', II-I5.xii.I9II, 3 오 I ơ (S. A. Neave); Entebbe, I-II.ix.I9II, I 오 I oै (S. A. Neave); Entebbe, I2-I4.X.I9I4, I ㅇ (C. C. Gowdey); Kivuvu, I9.viii. I9I3, I ㅇ (C. C. Gowdey); Kampala, I3.ix.I9I5, I ㅇ (C. C. Gowdey); Bugalla Island, viii.I929, I ô (G. D. H. Carpenter); Namulala Forest, 27.x.I925, 2 ô (G. L. R. Hancock) (BMNH); Mabira Forest, 2I.v.I952, I 우 (NMSR). ZAIRE: Bokuma, ii-iv.I94I, gynandromorph (P. Hulstaert); Kivu, R. Tshinganda, iii.I950, I 우 (G. Marlier); Kivu, Mingazi, I95I, 2 우 (H. Bomans); Kibali-Ituri, Yindi, x.I948iii.I949, I 우 (A. E. Bertrand); Haute-Uele, Moto, xi.I923, I 우 (L. Burgeon); Dika, iii.I925, I oै (H. Schouteden) (paratype of E. multipictus); Bambili, I ô (Rodhain) (paratype of E. multipictus); Paulis, xii.I947, 2 ㅇ (P. L. G. Benoit); Dingila, v. I933, I ㅇ (H. J. Bredo); Medje, Io.vii.IgIo, I ô (Lang \& Chapin); Bambesa, viii. I933, I 우 I5.ix.I933, I ㅇ (paratype of var. ornatus); xi-xii.I933, I ㅇ, 4 o (H. J. Bredo); ii.I937, I o; iv.I937, 4 우 (J. Vrydagh) (MRAC); I5-I9.ix.I938, I 우 (J. Vrydagh) (IRSNB); xii.I946, I 우 (P. L. G. Benoit); Eala, vii-xii.I935, 3 우, 2 ô (I 우 paratype of var. ornatus) (H. J. Bredo); Bayenga, I2.xi.I956, I ㅇ (R. Castelain); Ubangi, Abumombazi, 23.ii.I932, I 우 (paratype of var. ornatus) (H. J. Bredo); Kilo, Mongbwalu, vii.I937, I + (Scheitz); Thysville, 30.xi.r952, I ô (P. Basilewsky); Sankuru, Komi, 4.ii.I930, I ô (J. Ghesquière) (paratype of E. multipictus); Stanleyville, iii.I926, I 우 (J. Ghesquière) (MRAC); Coquilatville, I 우 (NMSR); Beni, II20 m, ii.I93I, I ơ (L. Lebrun); Ponthlerville, 24.vii.I947, I + (M. Poll); Kwango, Panzi, I2.ii.I939, I 우 (Bequart) (MRAC); Uele, Poko, viii.IgI3, I 우 (Lang \& Chapin); Bas-Uele, I ; : Equateur, I + (coll. Wahis). 


\section{REFERENCES}

Arnold, G. I937. The Psammocharidae of the Ethiopian region. Part VII. Subfamily Psammocharinae continued. Ann. Transv. Mus. 19 : I-98.

1952. New species of African Hymenoptera. Io. Occ. Pap. natn. Mus. Sth. Rhod. $17: 46 \mathrm{I}-493$.

I955. Contributions à l'étude de la faune entomologique du Ruanda-Urundi (Mission P. Basilewsky 1953). 4I. Hymenoptera Pompilidae. Annls Mus. r. Congo Belge Ser. $8^{\circ}$ Sci. Zool. $36: 354-36$ I.

Ashmead, W. H. I902. Classification of the fossorial, predaceous and parasitic wasps of the superfamily Vespoidea. Part 4. Can. Ent. 34 : 79-88.

Banks, N. I9I7. New fossorial Hymenoptera. Bull. Mus. comp. Zool. Havv. 61 : 97-II5. 1934. The Psammocharidae of the Philippines. Proc. Am. Acad. Arts Sci. 69 (I) : I-I I7. 1938. Some Psammocharidae from Singapore. Proc. ent. Soc. Wash. $40: 236-249$.

I94I. Some Psammocharidae from Madagascar (Hymenoptera). Proc. Acad. nat. Sci. Philad. 92 (I940) : 335-362.

DAlla TORRE, C. G. DE. I897. Catalogus Hymenopterorum hucusque descriptorum systematicus et synonymicus. 8 . viii +749 pp. Leipzig.

Dufour, L. I834. Observation sur une nouvelle espèce d'Anoplius qui n'offre qu'un seule ocelle. Annls Soc. ent. Fr. $2: 483-485$.

Evans, H. E. I95I. A taxonomic study of the Nearctic spider wasps belonging to the tribe Pompilini (Hymenoptera: Pompilidae). Part II: Genus Anoplius Dufour. Trans. Am. ent. Soc. $76:$ 207-36r.

- r966. A revision of the Mexican and Central American spider wasps of the subfamily Pompilinae (Hymenoptera: Pompilidae). Mem. Am. ent. Soc. 20 : I-442.

Haupt, H. I929. Weiterer Ausbau meines Systems der Psammocharidae. Mit Beschreibung neuer Gattungen und Arten. Mitt. zool. Mus. Berl. 15 : ro9-197.

- 1935. In von Schulthess Rechberg, Hymenoptera aus den Sundainseln und Nordaustralien. Revue suisse Zool. 42 (2) : 293-323.

I938a. Zur Kenntnis der Psammochariden-Fauna der nordöstlichen China und der Mongolei. Ark. Zool. 30A (4) : I-26.

1938b. Psammocharidae vom unteren Yang-Tse. Notes Ent.chin. 5 : 33-48.

I94I. Resultate der Oxford Universität Expedition nach Sarawak (Borneo), I932. Beitrag zur Kenntnis der Psammochariden Fauna. Ann. Mag. nat. Hist. (I I) $7: 50-82$.

— 1950. Pompilidae (Hymenoptera Sphecoidea). Explor. Parc natn. Albert Miss. G. F. de Witte. 69 : I-63.

Howard, L. O. I901. The Insect Book. xxvii+429 pp. New York.

Koнl, F. F. 1884. Die Gattungen der Pompiliden. Verh. zool-bot. Ges. Wien 34 : 33-58.

Latreille, P. A. I796. Précis des caractères génériques des insectes, disposés dans un ordre naturel. xiii+7-20I pp. Brive.

- I803. Nouveau dictionnaire d'histoire naturelle. Tome 21. I-57I pp. Paris.

Pate, V. S. L. I946. The generic names of the spider wasps (Psammocharidae olim Pompilidae) and their type species. Trans. Am. ent. Soc. $72: 65^{-1} 30$.

Ritsema, C. I874. Aanteekeningen betreffende eene kleine collectie Hymenoptera van Neder-Guinea, en beschrijving van die nieuwe soorten. Tijdschr. Ent. 17 : I75-2II.

SAEger, H. DE. I945. Contribution à l'étude des Hyménoptères du Congo Belge: Pompilidae. Revue Zool. Bot. afr. 39 : 78-II4.

Saussure, H. DE. I867. Hymenoptera. Familien der Vespiden, Sphegiden, Pompiliden, Crabroniden und Heterogynen. Reise der Österreichischen Fregatte Novara um die Erde. I857-I859. Zool. Th., Bd. 2 : I-I 56. Wien.

I89r. Hyménoptères nouveaux de Madagascar. Mitt. schweiz. ent. Ges. 8 (7) : 253-269. I892. Histoire physique, naturelle et politique de Madagascar. XX. Histoire naturelle des Hyménoptères. I77-590 pp., pls 21-27. Paris. 
Sмiтн, F. I855. Catalogue of the hymenopterous insects in the collection of the British Museum Part III. Mutillidae and Pompilidae. 206 pp. London.

- I857. Catalogue of the hymenopterous insects collected at Sarawak, Borneo; Mont Ophir, Malacca; and at Singapore by A. R. Wallace. J. Linn. Soc. 2 : 42-rzo.

- I86I. Descriptions of new species of hymenopterous insects collected by Mr A. R. Wallace at Celebes. J. Linn. Soc. $5:$ 57-93.

- I873. Descriptions of new species of fossorial Hymenoptera in the collection of the British Museum. Ann. Mag. nat. Hist. (4)11 : 44I-45I.

- 1879. Descriptions of new species of Hymenoptera in the collection of the British Museum. $\mathrm{xxi}+240 \mathrm{pp}$. London.

Strand, E. I9I I. Über die von Herrn Ingenieur E. Hintz in Kamerun gesammelten Hymenoptera, mit Beiträgen zur Kenntnis afrikanischer Paniscus-Arten. Mitt. zool. Mus. Berl. $5: 485-503$.

Taschenberg, E. I869. Die Pompiliden des Museums der Universität zu Halle. Z. ges. Naturw. Halle $34: 25-75$.

Tullgren, A. I904. On some Hymenoptera Aculeata from the Cameroons. Ark. Zoo. $1: 425-463$.

Turner, R. E. I9I7. New species of Hymenoptera in the British Museum. Trans. ent. Soc. Lond. $50: 53-84$.

Vecht, J. van Der \& Menke, A. S. I968. Anoplius Dufour, I834 (Insecta, Hymenoptera): proposed designation of a type-species with proposed designation of neotypes under the plenary powers for Sphex nigra Fabricius, I775 and Sphex nigerrimus Scopoli, I763. Bull. zool. Nom. 25 : I20-I 24.

Wolf, H. I963. Die nord- und mitteleuropaischen Arten der Gattung Anoplius Dufour, I834 (Hym.: Pompilidae). Opusc. ent. 28 : I29-I44.

\section{IN DEX}

Junior synonyms and other invalid names are in italics.

aciculatus, 388

aethiopicus, 390

Africanoplius, 380

analis, 388

Anopliodes, 378

Anoplius s. str., 378

apicalis Haupt, 1929, 400

apicalis Haupt, 1938, 379

Arachnophroctonus, 379

atropos, 382

bahimae, 396

bavinganus, 400

bifasciatus, 400 .

Cameronoplius, 378

canifrons, 382

consimilis, 379

decoratus, 388

Elaphrosyron, 400, 401 elongatus Lepeletier, 388

elongatus Ritsema, 388

exclusus, 379

ignobilis, 380,382

jocaste, 394

leucopheus, 382

limbatus, 382

Lophopompilus, 378

melas, 379

minutidens, 379

morosus, 380,388

multipictus, 400

niger, 379

nigripes, 396

nigrocaeruleus, 382

nitens, 379

Notiochares, 379 obscuratus, 379

Orientanoplius, 378,380

ornatus, 400

plebeius Saussure, 394

plebejus Dahlbom, 394

plebejus Saussure, 394

pluto, 382

plutonis, 376

Pompilinus, 379

Psammochares, 377,379

vitsemae, 388

rufipes, 387

rufounguiculatus, 382

saegeri, 394

Tagalochares, 376

umtaliensis, 390

viridicatus, 379

M. C. DAY, B.Sc.

Department of Entomology

British Museum (Natural History)

Cromwell RoAd

LoNDON $\mathrm{SW}_{7}{ }_{5} \mathrm{BD}$ 


\section{$2 \mathrm{BHL}$ Biodiversity Heritage Library}

1974. "A contribution to the taxonomy of the genus Anoplius Dufour (Hymenoptera: Pompilidae) including a revision of the Palaeotropical subgenus Orientanoplius Haupt." Bulletin of the British Museum (Natural History) Entomology 30, 373-404. https://doi.org/10.5962/bhl.part.24944.

View This Item Online: https://www.biodiversitylibrary.org/item/19430

DOI: https://doi.org/10.5962/bhl.part.24944

Permalink: https://www.biodiversitylibrary.org/partpdf/24944

\section{Holding Institution}

Natural History Museum Library, London

\section{Sponsored by}

Natural History Museum Library, London

\section{Copyright \& Reuse}

Copyright Status: In copyright. Digitized with the permission of the rights holder.

Rights Holder: The Trustees of the Natural History Museum, London

License: http://creativecommons.org/licenses/by-nc-sa/4.0/

Rights: http://biodiversitylibrary.org/permissions

This document was created from content at the Biodiversity Heritage Library, the world's largest open access digital library for biodiversity literature and archives. Visit BHL at https://www.biodiversitylibrary.org. 